Andrews University

Digital Commons @ Andrews University

1999

\title{
An Evangelistic Strategy for Reaching Baby Boomers in Rock Island County, Illinois
}

Clarence H. Small

Andrews University

Follow this and additional works at: https://digitalcommons.andrews.edu/dmin

Part of the Practical Theology Commons

\section{Recommended Citation}

Small, Clarence H., "An Evangelistic Strategy for Reaching Baby Boomers in Rock Island County, Illinois" (1999). Professional Dissertations DMin. 702.

https://dx.doi.org/10.32597/dmin/702

https://digitalcommons.andrews.edu/dmin/702

This Project Report is brought to you for free and open access by the Graduate Research at Digital Commons @ Andrews University. It has been accepted for inclusion in Professional Dissertations DMin by an authorized administrator of Digital Commons @ Andrews University. For more information, please contact repository@andrews.edu. 


\section{ABSTRACT}

\section{AN EVANGELISTIC STRATEGY FOR REACHING BABY \\ BOOMERS IN ROCK ISLAND COUNTY, ILLINOIS}

by

Clarence H. Small

Adviser: Kenneth Stout 


\title{
ABSTRACT OF GRADUATE STUDENT RESEARCH
}

Dissertation

\author{
Andrews University \\ Seventh-day Adventist Theological Seminary \\ Title: AN EVANGELISTIC STRATEGY FOR REACHING BABY BOOMERS IN \\ ROCK ISLAND COUNTY, ILLINOIS \\ Name of researcher: Clarence $H$. Small \\ Name and degree of faculty advisor: Kenneth Stout, Ph.D. \\ Date completed: June 1999
}

Problem

The Moline Seventh-day Adventist Church, with a regularly attending membership of approximately 65, has fifteen Baby Boomer members in a county of over 160,000 , of whom at least 44,000 are Boomers, with over 30,000 of these being unchurched. This project sought to develop a strategy for attracting Baby Boomers to the Moline church.

\section{Method}

A strategy was developed and implemented to attract Baby Boomers to church based upon six valid and transferable principles drawn from existing literature and the successful programs of the Willow Creek and Saddleback churches-and the clearly 
established legitimacy of targeting specific groups for evangelism. This strategy included: (1) a prayer offensive using door hangers to invite community members to pray for the community; (2) a community survey to ascertain felt needs; (3) a Seeker Service; and (4) an evangelistic series using satellite downlink technology.

\section{Results}

While the strategy is based upon valid foundational principles and assumptions, it met with varying degrees of acceptance by members of the Moline Adventist church, and with little success in reaching out to Baby Boomers in the targeted community. While the concepts of targeted evangelism were accepted on an intellectual basis by most members, there was little or no personal involvement in the evangelistic outreach as needed for the strategy to succeed. The major hindrance to the project's success was not, therefore, the principles employed, or the overall strategy itself, but the inability to illicit commitment from the members or to moboilize active support for the strategy by the host church.

\section{Conclusions}

A major change in organizational methodology such as this project sought to bring about requires significant time, careful planning and implementation, and a sense of urgency that the changes are needed. Without these elements, the change will not succeed. Church leaders and members need to develop a sense of eschatological urgency based on the promise of the soon return of Jesus and the sense that many of those in our communities will be lost unless they come into relationship with Jesus. 
Andrews University

Seventh-day Adventist Theological Seminary

\title{
AN EVANGELISTIC STRATEGY FOR REACHING BABY BOOMERS IN ROCK ISLAND COUNTY, ILLINOIS
}

\author{
A Dissertation \\ Presented in Partial Fulfillment \\ of the Requirements for the Degree \\ Doctor of Ministry
}

by

Clarence H. Small

June 1999 



\title{
AN EVANGELISTIC STRATEGY FOR REACHING BABY \\ BOOMERS IN ROCK ISLAND COUNTY, ILLINOIS
}

\author{
A project report \\ presented in partial fulfillment \\ of the requirements for the degree \\ Doctor of Ministry
}

by

Clarence H. Small

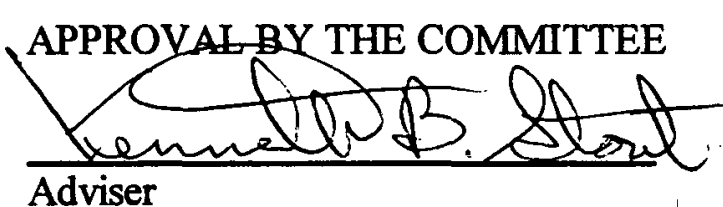

Kenneth Stout
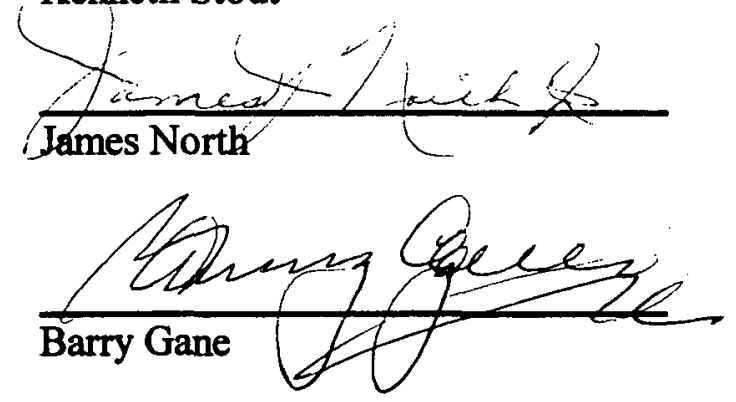

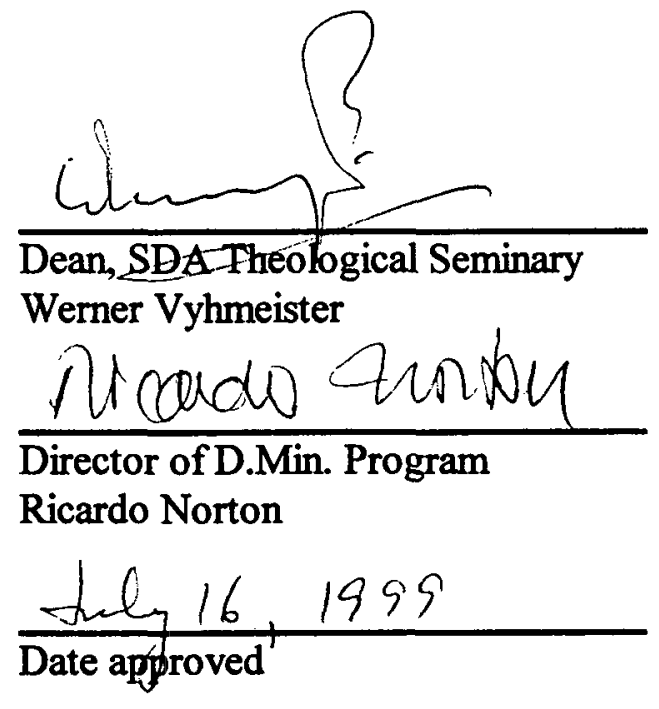


In appreciation to my parents, James and Katherine Small, who gave me a love for books and knowledge.

To Chris and Loren, who gave me courage.

To Ginger, "It is finished."

In memory of Jody Stout, and in special appreciation to

Dr. Kenneth Stout, who worked with me in finishing this project despite his great loss. 


\section{TABLE OF CONTENTS}

LIST OF ILLUSTRATIONS $\ldots \ldots \ldots \ldots \ldots \ldots \ldots \ldots \ldots \ldots \ldots \ldots$ vi

LIST OF TABLES $\ldots \ldots \ldots \ldots \ldots \ldots \ldots \ldots \ldots \ldots \ldots \ldots \ldots \ldots$ vi

Chapter

1. INTRODUCTION $\ldots \ldots \ldots \ldots \ldots \ldots \ldots \ldots \ldots \ldots \ldots \ldots \ldots \ldots \ldots \ldots$

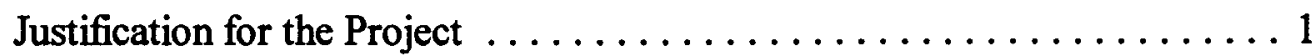

Limitations of the Project $\ldots \ldots \ldots \ldots \ldots \ldots \ldots \ldots \ldots \ldots \ldots \ldots$

Methodology of the Project ....................... 12

2. THEOLOGICAL FOUNDATIONS FOR TARGETING

EVANGELISTIC AUDIENCES $\ldots \ldots \ldots \ldots \ldots \ldots \ldots \ldots \ldots \ldots \ldots$

A Biblical Background for Targeted Evangelism ............. 14

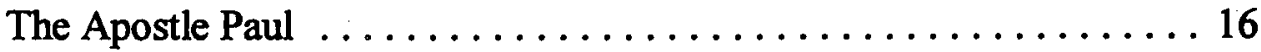

The Prophet Jonah .......................... 17

Nineveh a Receptive Audience $\ldots \ldots \ldots \ldots \ldots \ldots \ldots$. . . . 19

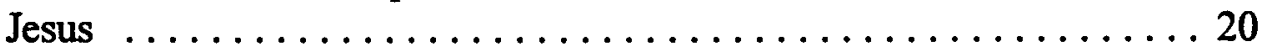

Ellen White's Views on Targeted Evangelism .............. 23

The Church-Growth Movement and Targeted Evangelism . . . . . . . 27

3. TARGETING BABY BOOMERS $\ldots \ldots \ldots \ldots \ldots \ldots \ldots \ldots \ldots \ldots \ldots \ldots \ldots \ldots \ldots$

Defining the Baby Boom Generation $\ldots \ldots \ldots \ldots \ldots \ldots \ldots \ldots \ldots \ldots$

Marketing to Baby Boomers: The Challenge of

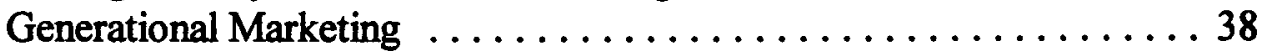

Localizing Generational Marketing $\ldots \ldots \ldots \ldots \ldots \ldots \ldots \ldots, \ldots \ldots \ldots$

Localizing and Personalizing Evangelism $\ldots \ldots \ldots \ldots \ldots \ldots \ldots 46$

4. CURRENT SUCCESSFUL APPROACHES TO BABY BOOMERS $\ldots \ldots \ldots 49$

The Willow Creek Model $\ldots \ldots \ldots \ldots \ldots \ldots \ldots \ldots \ldots \ldots \ldots . \ldots 49$

Willow Creek's Background . . . . . . . . . . . . . . . . 49 
Criticisms of Willow Creek . . . . . . . . . . . . . . . 52

Successfully Targeting Baby Boomers $\ldots \ldots \ldots \ldots \ldots \ldots \ldots \ldots 6$

The Saddleback Model . .......................6 60

Saddleback Community Church's Background ............6 61

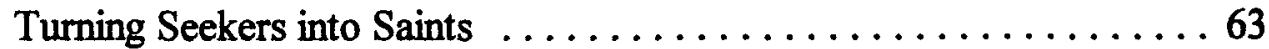

Targeting Baby Boomers $\ldots \ldots \ldots \ldots \ldots \ldots \ldots \ldots \ldots 66 \ldots \ldots \ldots \ldots \ldots$

Transferable Principles from Willow Creek and Saddleback ........ 68

5. AN EVANGELISTIC MODEL FOR REACHING BABY BOOMERS . . . . 71

Applying Transferable Principles $\ldots \ldots \ldots \ldots \ldots \ldots \ldots \ldots \ldots \ldots \ldots$

A Strategy for Reaching Baby Boomers $\ldots \ldots \ldots \ldots \ldots \ldots \ldots \ldots, 72$

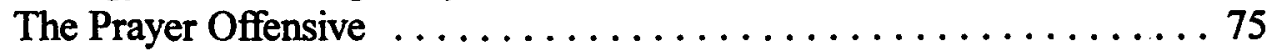

The Community Survey $\ldots \ldots \ldots \ldots \ldots \ldots \ldots \ldots \ldots \ldots \ldots$

The Seeker Service . . . . . . . . . . . . . . . . . . . 83

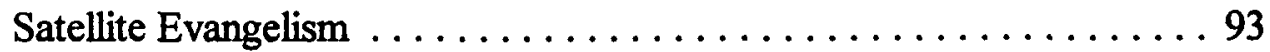

Summary of Project Results $\ldots \ldots \ldots \ldots \ldots \ldots \ldots \ldots \ldots \ldots$

6. SUMMARY, CONCLUSIONS, AND RECOMMENDATIONS $\ldots \ldots \ldots \ldots 101$

Summary ............................... 101

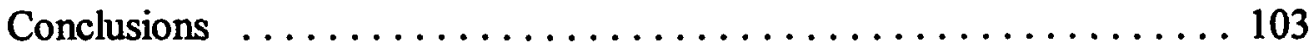

Recommendations ........................... 109

Appendix

A. MOLINE SEVENTH-DAY ADVENTIST CHURCH

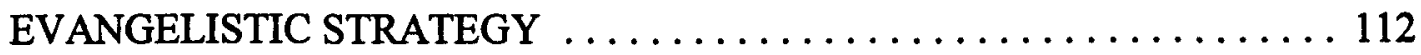

B. PRAYER OFFENSIVE DOOR HANGER $\ldots \ldots \ldots \ldots \ldots \ldots \ldots \ldots \ldots \ldots \ldots$

C. COMMUNITY QUESTIONNAIRE, RESULTS, AND INSTRUCTIONS . . . 115

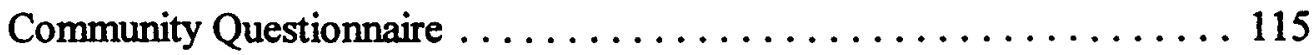

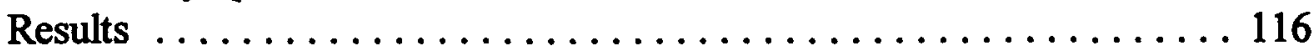

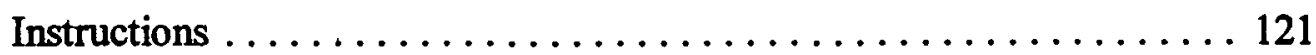

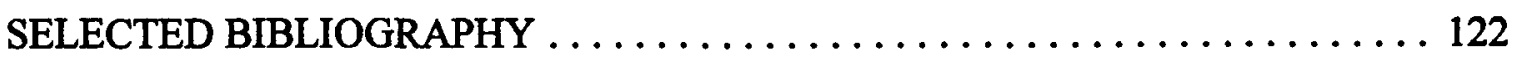

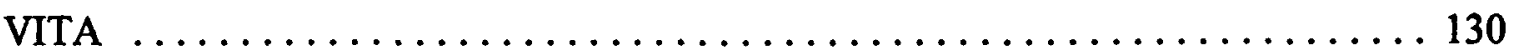




\section{LIST OF ILLUSTRATIONS}

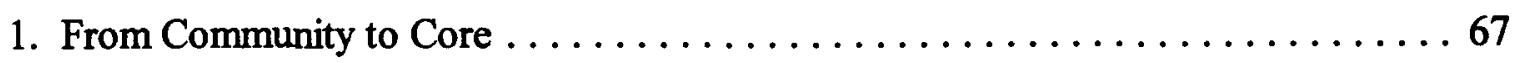

2. Change Results Based on Balance of Leadership/Courage and Management/Consideration

\section{LIST OF TABLES}

1. Total Population of the Quad Cities, $1990 \ldots \ldots \ldots \ldots \ldots \ldots \ldots \ldots \ldots \ldots \ldots \ldots \ldots \ldots$

2. Quad Cities Population by Age, $1990 \ldots \ldots \ldots \ldots \ldots \ldots \ldots \ldots \ldots \ldots \ldots \ldots \ldots \ldots \ldots \ldots$

3. Baby Boomers in the Quad Cities Population, $1990 \ldots \ldots \ldots \ldots \ldots \ldots$

4. Quad Cities Racial Make-up, $1990 \ldots \ldots \ldots \ldots \ldots \ldots \ldots \ldots \ldots \ldots \ldots \ldots \ldots \ldots \ldots \ldots$

5. Rock Island County Racial Percentages, $1990 \ldots \ldots \ldots \ldots \ldots \ldots \ldots \ldots$

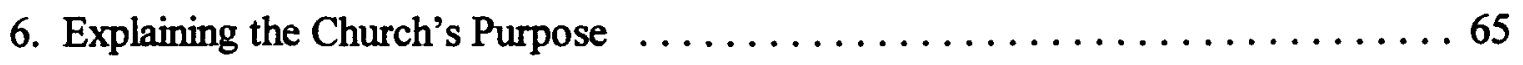

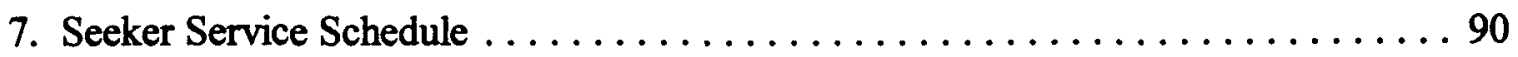




\section{CHAPTER I}

\section{INTRODUCTION}

The purpose of this project was to develop and carry out a Seventh-day Adventist evangelistic strategy for reaching Baby Boomers ${ }^{1}$ in Rock Island County, Illinois. This paper describes the strategy and reports on its development, implementation, and evaluation.

\section{Justification for the Project}

A project with the scope proposed deserves some justification. Listed below are the justifying reasons for this project which, taken together, offer powerful and persuasive support for undertaking this project.

First, statistics point to a lower than expected representation of Boomers in the Adventist and other Christian churches in Rock Island County. The Quad Cities area has a population of 299,000 (see tables 1 and 2) which is split between Scott County, Iowa, and Rock Island County, Illinois. Principal cities include Bettendorf and Davenport, Iowa, and Rock Island and Moline, Illinois. In addition, smaller cities in both counties add

${ }^{1}$ The Baby Boom after World War II began in 1946 and continued until 1964. Those born during this period are known as Baby Boomers. More details are given in chapter 3. 
to the population. ${ }^{1}$ According to City of Moline Mayor Stan Leech, if Rock Island County incorporated as a municipal government it would form the second largest city in Illinois. $^{2}$

\section{TABLE 1}

TOTAL POPULATION OF THE QUAD CITIES, 1990

\begin{tabular}{lcccc}
\hline & Moline City & $\begin{array}{c}\text { Rock Island } \\
\text { County }\end{array}$ & Scott County & $\begin{array}{c}\text { Total } \\
\text { Population }\end{array}$ \\
\hline Persons & 43,202 & 148,729 & 150,979 & 299,708 \\
Families & 11,884 & 39,939 & 40,386 & 80,325 \\
\hline
\end{tabular}

Such a population base should have a significant Adventist presence. Yet on any given Sabbath, fewer than 250 Seventh-day Adventists meet for worship and study in the entire Quad Cities area, and only 65 in Rock Island County. ${ }^{3}$ There are, perhaps, another 200 to 300 who claim Adventist membership but do not attend. The largest single identifiable group in the population is Baby Boomers, approximately 44,000 in number on the Illinois side of the Mississippi River alone. (See table 3.) Even if only one percent of

1'"1990 Census of Population and Housing, Illinois, Rock Island County" [online]; available from http://venus.census.gov/cdrom/lookup; Internet. Census data break this down in many ways. The part of interest for this project is the age breakdown.

${ }^{2}$ Stan Leech, Mayor of Moline, IL, in a discussion with the Moline Ministerial Association, September 16, 1997.

${ }^{3}$ There are three Adventist churches in the Quad Cities: Moline Seventh-day Adventist Church in Rock Island County, Calvary Seventh-day Adventist Church and Davenport Seventh-day Adventist Church in Scott County, Iowa. Calvary is predominantly Black, with an average attendance of 65 . The Moline and Davenport Churches are predominantly White. Davenport's average attendance is approximately 85 , and Moline's is 65. 
TABLE 2

QUAD CITIES POPULATION BY AGE, 1990

\begin{tabular}{|c|c|c|c|c|}
\hline Age & Moline, IL & $\begin{array}{l}\text { Rock Island } \\
\text { County, IL }\end{array}$ & $\begin{array}{c}\text { Scott County, } \\
\text { IA } \\
\end{array}$ & $\begin{array}{c}\text { Total } \\
\text { Population } \\
\end{array}$ \\
\hline Under 1 & 532 & 1,667 & 2,088 & 3,755 \\
\hline $1-2$ & 1,283 & 4,473 & 4,888 & 9,361 \\
\hline $3-4$ & 1,207 & 3,991 & 4,802 & 8,793 \\
\hline 5 & 595 & 2,119 & 2,413 & 4,532 \\
\hline 6 & 601 & 2,139 & 2,417 & 4,556 \\
\hline $7-9$ & 1,847 & 6,667 & 7,364 & 14,031 \\
\hline $10-11$ & 1,262 & 4,552 & 4,875 & 9,427 \\
\hline $12-13$ & 1,171 & 4,087 & 4,682 & 8,769 \\
\hline 14 & 574 & 2,039 & 2,338 & 4,377 \\
\hline 15 & 591 & 2,198 & 2,144 & 4,342 \\
\hline 16 & 539 & 1,931 & 2,116 & 4,047 \\
\hline 17 & 546 & 2,007 & 2,080 & 4,087 \\
\hline 18 & 516 & 1,999 & 2,093 & 4,092 \\
\hline 19 & 519 & 2,359 & 2,127 & 4,486 \\
\hline 20 & 507 & 2,158 & 2,122 & 4,280 \\
\hline age 21 & 566 & 2,175 & 1,883 & 4,058 \\
\hline $22-24$ & 1,637 & 5,447 & 6,611 & 12,058 \\
\hline $25-29$ & 3,125 & 10,366 & 12,088 & 22,454 \\
\hline $30-34$ & 3,704 & 12,109 & 13,116 & 25,225 \\
\hline $35-39$ & 3,378 & 11,740 & 12,566 & 24,306 \\
\hline $40-44$ & 2,985 & 10,243 & 11,080 & 21,323 \\
\hline $45-49$ & 2,444 & 8,490 & 8,653 & 17,143 \\
\hline $50-54$ & 2,051 & 7,363 & 7,069 & 14,432 \\
\hline
\end{tabular}


Table 2-Continued.

\begin{tabular}{ccccc}
\hline $55-59$ & 1,969 & 8,728 & 6,228 & 14,956 \\
$60-61$ & 881 & 3,002 & 2,400 & 5,402 \\
$62-64$ & 1,267 & 4,369 & 3,543 & 7,912 \\
$65-69$ & 2,065 & 6,867 & 5,708 & 12,575 \\
$70-74$ & 1,882 & 5,985 & 4,321 & 10,306 \\
$75-79$ & 1,438 & 4,441 & 3,251 & 7,692 \\
$80-84$ & 893 & 2,601 & 2,241 & 4,842 \\
85 and over & 626 & 2,422 & 1,807 & 4,229 \\
\hline
\end{tabular}

the Baby Boomers in Rock Island County joined an Adventist church, the Adventist membership would nearly triple and Christianity's presence would therefore be increased in Rock Island County.

The racial makeup of Rock Island County is also interesting (see table 4). The data makes clear that Whites are an overwhelming majority of the population, and that African Americans and Hispanics (the second and third largest groups respectively) are important, but very small, minorities (see table 5). Any evangelistic strategy will need to take into consideration that the pool of Baby Boomers in this area is primarily White in racial makeup. 
TABLE 3

BABY BOOMERS IN THE QUAD CITIES POPULATION, 1990

\begin{tabular}{ccc}
\hline & Number of Baby Boomers & Percent of Tot. Pop. \\
\hline Moline City & 13,192 & 30.54 \\
Rock Island County & 44,458 & 29.89 \\
Scott County & 48,850 & 32.36 \\
\hline Total Population & 93,308 & 31.13 \\
\hline
\end{tabular}

TABLE 4

QUAD CITIES RACIAL MAKE-UP, 1990

\begin{tabular}{lcccc}
\hline Race & Moline City & $\begin{array}{c}\text { Rock Island } \\
\text { County }\end{array}$ & Scott County & $\begin{array}{c}\text { Total } \\
\text { Population }\end{array}$ \\
\hline White & 40,658 & 133,451 & 139,408 & 272,859 \\
Black & 865 & 10,476 & 7,970 & 18,446 \\
American & 93 & 496 & 485 & 981 \\
Indian & 368 & 932 & 1,759 & 2,691 \\
Asian & 2,939 & 8,084 & 4,253 & 12,337 \\
Hispanic & 1,218 & 3,368 & 1,759 & 5,127 \\
Other & & & & \\
\hline
\end{tabular}


TABLE 5

ROCK ISLAND COUNTY RACIAL PERCENTAGES, 1990

\begin{tabular}{lrrrr}
\hline Race & Moline City & $\begin{array}{c}\text { City Population } \\
\text { Percent }\end{array}$ & $\begin{array}{c}\text { Rock Island } \\
\text { County }\end{array}$ & $\begin{array}{c}\text { County } \\
\text { Population } \\
\text { Percent }\end{array}$ \\
\hline White & 40,658 & 88.12 & 133,451 & 85.11 \\
Black & 865 & 1.87 & 10,476 & 6.68 \\
American Indian & 93 & 0.20 & 496 & 0.32 \\
Asian & 368 & 0.80 & 932 & 0.59 \\
Hispanic & 2,939 & 6.37 & 8,084 & 5.16 \\
Other & 1,218 & 2.64 & 3,368 & 2.15 \\
\hline Total & 46,141 & 100.00 & 156,807 & 100.00 \\
\hline
\end{tabular}

A look at the numbers indicates the need for an evangelistic strategy to target the most significant population groups in this area. The largest single identifiable group is Baby Boomers. These numbers alone would be sufficient reason for the development of a strategy. However, there are other important reasons.

Second, Baby Boomers constitute what has been called a "missing generation"' to the church, and, therefore, they need to be more effectively sought out and brought to the circle of Christian fellowship. Since I left high school in the mid-sixties, I have watched classmates and friends leave the Seventh-day Adventist Church, many finding no other church home, and some rejecting faith in God completely. A number are beginning to come back, but many feel no desire to be part of the Adventist church or any other church.

'Robert L. Bast, The Missing Generation (Monrovia, CA: Reformed Church in America, 1991), 22. 
The Baby Boom generation has impacted American society as no other generation since the founding fathers. Gary McIntosh states, "Enough Boomer babies came to create a 'pig-in-a-python' effect. As one can see the bulge of a pig moving through the digestive tract of a python, so the Boomer wave can be observed moving through society."1 George Barna reports that in 1996 only 31 percent of Boomers attended church weekly. ${ }^{2}$ Using that figure, there are over 30,000 unchurched Baby Boomers in Rock Island County.

I am a "first wave" Boomer, born in 1947. I feel a deep concern for those of my generation who have turned their back on the church. According to Barna and other statisticians, the Adventist church is not alone in facing this trend. While it is true that not all who have rejected organized religion have rejected God, I believe that there is a need to call the Baby Boom generation to the cross of Jesus Christ.

Third, leadership in the Christian church (including the Seventh-day Adventist Church) is suffering because of the missing Boomers. The Moline Seventh-day Adventist Church, for example, has approximately sixty-five regularly attending members. Twentyeight are members of the so-called "Mature Generation":

The members of the Mature generation were born between the turn of the Century and the end of World War II. ... This generation includes two waves of consumers-the GIs . . . and the Silents. .. . There are certainly some differences between these two subsets, but because they largely shared the

'Gary L. McIntosh, Three Generations: Riding the Waves of Change in Your Church (Grand Rapids, MI: Fleming H. Revell Company, 1995), 73.

${ }^{2}$ George Barna, "Has Revival Begun? Our Annual Report on the State of the Christian Church in America," The Barna Report 1, no. 6 (1997): 2. 
same generational experiences, the GIs and the Silents developed the same basic values and motivations. ${ }^{1}$

Fifteen church members are Baby Boomers, eight belong to what Diane Crispell labels the "Baby Bust,"2 and ten are part of the "Baby Boom Echo.""3 Boomers make up approximately a third of the total national population, including children, and almost 41 percent of the Rock Island County adult population. Based on the large number of Boomers in Rock Island County, it appears that the Moline Seventh-day Adventist Church has far fewer Boomers than one would expect.

As some Boomers approach their sixth decade, they are taking more and more leadership responsibility in business and government. Of our fifteen-member church board three are Baby Boomers, two are Generation Xers, and ten are from the Mature Generation. This means that only 20 percent of our Board members are Boomers. This is, again, a much lower percentage than one would expect by looking at county population figures.

\footnotetext{
'J. Walker Smith and Ann Clurman, Rocking the Ages: The Yankelovich Report on Generational Marketing (New York: HarperCollins Publishers, 1997), 18.

${ }^{2}$ Members of the so-called "Baby Bust" generational cohort don't care for the term. Many terms have been used, but the one which seems to be sticking, at the moment, is "Generation X," taken from the name of a 1991 novel. "Generation X" is often shortened to "GenX." See McIntosh, 130, for a fuller discussion.
}

${ }^{3}$ The literature currently defines seven generations in the United States: GI generation, born before 1930; Depression generation, 1930 to 1939; War babies, 1940 to 1945; Baby Boom, 1946 to 1964; Baby Bust, 1965 to 1976; Baby Boomlet, 1977 to 1995; and Echo Bust, beginning in 1996. The last two are based on an assumption that the Boomlet "will be an 18 year cohort as the original Baby Boom was." Diane Crispell, "Where Generations Divide: A Guide," American Demographics (May 1993): 9-10. 
Targeting Baby Boomers for evangelism could increase the pool of available talent for leadership positions in the church. As Boomers approach midlife, this pool would include people who are leaving the responsibility of raising children and, therefore, have more time to devote to volunteer activities such as exist within the church. Boomers in their forties and fifties likely will have more time for church leadership. The smaller percentage of Boomers in the Moline Adventist membership mix creates a serious leadership void.

Fourth, Baby Boomers may be more receptive as they are entering, or have already entered, the midlife years. This is often a time of significant change. Such change may open a window of opportunity for evangelism. This period of change is often referred to as "midlife crisis."1

In the October 8, 1996, issue of Brandweek, Joe Schwartz wrote:

Now we're moving toward the endgame. Earlier this year, the oldest members of this generation, born in 1946, began celebrating their 50th birthdays. As they did, brand managers and marketing executives pondered the long-term impact of this oversized generation moving onto the far side of middle age. ${ }^{2}$

Cheryl Russell, prolific writer on Baby Boom marketing issues, directly

addresses the issue of midlife crisis:

The impending 50th birthday of the oldest Baby Boomer is just a media event. But Boomers' midlife crises are real, and they will create huge business opportunities. Freed from the responsibilities of their 40s, Boomers will create an adventurous life stage called "midyouth" that

${ }^{1}$ Several books use this term. One Christian viewpoint is presented in Jim Conway, Men in Mid-Life Crisis (Elgin, IL: David C. Cook Publishing Co., 1978).

${ }^{2} J o e$ Schwartz, "Boomer Boom," Brandweek, October 8, 1996, $42-47$. 
will push traditional ideas of a "mature market" into oblivion. "Power Players," "Fun Seekers," and "Matriarchs" will typify Boomers in their 50s. ${ }^{1}$

There is plenty of anecdotal evidence to sketch out the midlife crises of Baby Boomers, but the evidence goes far beyond office gossip. The 1994 General Social Survey (GSS), conducted by the National Opinion Research Center of the University of Chicago, has statistically documented midlife crisis. GSS interviewers asked a nationally representative sample of Americans whether they had experienced any trauma in the past 12 months. Overall, 40 percent said they had. This proportion is lowest (27 percent) among people in their early 30 s. It is highest among the middle-aged, rising to 49 percent among people in their late 40 s and peaking at 53 percent among 50-to-54-year-olds. Invariably, the crises of midlife revolve around the things that are most important--families, jobs, and personal health. ${ }^{2}$

According to church-growth experts, such feelings of stress and trauma may provide a window of opportunity for evangelism with Baby Boomers. Charles Arn states it this way:

A well tested principle of church growth is that 'Unchurched people are most receptive to a change in life-style (i.e., becoming Christians and responsible church members) during periods of transition.' A period of transition is a span of time in which an individual's or family's normal everyday behavior patterns are disrupted by some irregular event that requires an unfamiliar response. It is known, on the other hand, that people in a personally stable situation, with few complications or unusual interruptions, are not as often open to radical departure from their established life-styles. ${ }^{3}$

The midlife crisis currently faced by Baby Boomers presents a unique window of opportunity for Christians doing evangelism among Boomers which may not come again December, 1995, 22.

'Cheryl Russell, "The Baby Boom Turns 50," American Demographics,

${ }^{2}$ Ibid.

${ }^{3}$ W. Charles Arn, "How to Find Receptive People," in The Pastor's Church Growth Handbook, ed. Win Arn (Pasadena, CA: Church Growth Press, 1979), 142. 
until Boomers reach retirement age. Adventists and other Christians are responsible to take advantage of this evangelistic opportunity.

Fifth, there is currently a shortage of effective evangelistic strategies within the Adventist and other Christian churches which specifically target Baby Boomers. It is my hope to develop an evangelistic strategy for Boomers which can be easily adapted to the needs of any community, and to share that strategy with others, including non-Adventists.

As I share findings from the research for this project and implement the developed evangelistic strategy, I hope that attitudes held by church members toward other generations (Boomers, Generation X, and Echo) will become more open and accepting.

Sixth, I have come to believe that God gives a mission to each individual. That mission is determined by the personality, experience and skills, passion, spiritual gifts and calling of the individual. I believe that God has given me a passion and a calling to reach out in a special way to unchurched and nominally churched Baby Boomers-especially since I am a Boomer myself. This project will enable me to fulfill this passion, both personally and professionally, by helping me further develop and refine my personal evangelistic knowledge and skills as a pastor.

\section{Limitations of the Project}

The first limitation is that this is an evangelistic project. It is not designed to engender spiritual growth among existing members, although that may be a result.

A second limitation is the geographic area specified for the project; i.e., the Rock Island County, Illinois, area. In some ways this area is already too large, in that the 
number of people involved in Rock Island County may be more than can be adequately addressed by a church the size of the Moline Seventh-day Adventist Church. In other ways, the area is too small, in that the market area is really a regional area, including at least two other Illinois counties and two additional Iowa counties. This geographical unit, nevertheless, seems the most appropriate for this study.

A third limitation is that the study uses the Moline Seventh-day Adventist Church as its primary outreach and operation base in terms of location and personnel.

Finally, a fourth limitation is the time frame. The project was carried out between September 1997 and January 1999.

\section{Methodology of the Project}

The methodology utilized in this project is research and experimentation. First, a biblically based rationale for targeting a specific people group, such as Baby Boomers, will be sought and-if valid-set forth as the basis for a proposed contemporary model.

Second, current literature regarding the identity, character, and significance of Baby Boomers will be explored to help shape evangelistic options for reaching them.

Third, existing programs and strategies which are already proving successful in reaching Boomers with the gospel will be examined in order to help formulate a more effective evangelistic model for reaching Boomers.

Fourth, based on the above research in the Bible, studies in church growth, current Boomer literature and existing evangelistic programs regarding Baby Boomers, a strategy for more successfully reaching Boomers will be developed, implemented, and 
evaluated in the context of the Rock Island County, Illinois, area and the Moline Seventhday Adventist Church. 


\section{CHAPTER II}

\section{THEOLOGICAL FOUNDATIONS FOR TARGETING EVANGELISTIC AUDIENCES}

In this section, an examination is made of the Bible and the writings of Ellen White to establish the legitimacy and appropriateness of evangelistically targeting specific groups-such as Baby Boomers. Applicable church growth concepts are also briefly examined for their help in better deciphering and comprehending theological principles related to targeted evangelism.

Ellen White's writings are looked at because she is a respected authority and prolific writer within the Seventh-day Adventist church on evangelism and because Adventists believe that she has much to offer in terms of theoretical and theological insights in this area. It should be made clear, however, that the Bible is the primary source for Adventists-including this author-and, therefore, is the ultimate and most important source for the theological foundations of this chapter, as well as the overall project.

\section{A Biblical Background for Targeted Evangelism}

Does the Bible clearly present justification for evangelistically targeting specific groups of people such as Baby Boomers, or must we always take a global approach to evangelism? In attempting to answer this question, we must first acknowledge that Jesus 
Himself commissioned us to think globally and intentionally aim at, ultimately, evangelizing the world. When speaking to His disciples, He said:

All authority has been given to Me in heaven and on earth. Go therefore and make disciples of all the nations, baptizing them in the name of the Father and of the Son and of the Holy Spirit, teaching them to observe all things that I have commanded you; and lo, I am with you always, even to the end of the age. (Matt 28:18-20)

Evangelism, as commanded by Christ, therefore can be seen as the mission of the entire church; a mission which encompasses the whole world. We are all commanded and empowered to "Go ... and make disciples of all the nations...."

Preaching the gospel-evangelism-is a major focus for all Christians. But how can we most effectively and efficiently go about this immense task is an important question that has consumed countless hours of discussion and endless debate among advocates of different evangelistic styles and approaches. Thus, the significance of the issue posed in this section of the paper: Must we always engage in evangelistic techniques which seek to attract a wide population base, or are other approaches, targeted at more narrowly defined specific population groups, acceptable? A brief look at some concrete examples of targeted evangelism from Scripture will help answer the question for Christians engaged in evangelistic outreach.

As Christians, we accept Scripture as our model for faith and work. Finding evidence of targeted evangelism in Scripture should indicate that targeting specific audiences for gospel proclamation is an appropriate evangelistic approach for

${ }^{1}$ All texts are NKJV unless identified otherwise. 
contemporary usage. Such evidence is found in the experience of some of God's evangelists in both the Old and New Testaments.

\section{The Apostle Paul}

The apostle Paul had a very clear vision of targeted evangelism. He felt strongly that he had been called to target a specific evangelistic audience almost to the exclusion of all others:

Now in the church that was at Antioch there were certain prophets and teachers: Barnabas, Simeon who was called Niger, Lucius of Cyrene, Manaen who had been brought up with Herod the tetrarch, and Saul. As they ministered to the Lord and fasted, the Holy Spirit said, "Now separate to Me Barnabas and Saul for the work to which I have called them." Then, having fasted and prayed, and laid hands on them, they sent them away. (Acts 13:13)

Notice that this special assignment came directly from God through the "Holy Spirit." This assignment had been shown to the prophet Ananias at the time of Paul's conversion when Ananias objected to healing Paul, then known as Saul: "But the Lord said to him, 'Go, for he is a chosen vessel of Mine to bear My name before Gentiles, kings, and the children of Israel"' (Acts 9:15).

The book of Acts is clear: Paul and Barnabas traveled throughout Asia Minor and Greece preaching the gospel and establishing churches. When Paul finally returned to Antioch he reported what God had been doing through him and specifically stated that God had used him to target-and reach out with the gospel-to the Gentiles. The biblical record continues, reinforcing the identity of a special target group opened by God for Paul to work with: 
From there they sailed to Antioch, where they had been commended to the grace of God for the work which they had completed. Now when they had come and gathered the church together, they reported all that God had done with them, and that $\mathrm{He}$ had opened the door of faith to the Gentiles. (Acts 14:26-27)

Paul, afterwards, concentrated his career on preaching to the Gentiles. Notice

these verses:

Nevertheless, brethren, I have written more boldly to you on some points, as reminding you, because of the grace given to me by God, that I might be a minister of Jesus Christ to the Gentiles, ministering the gospel of God, that the offering of the Gentiles might be acceptable, sanctified by the Holy Spirit. (Rom. 15:15-16)

To me, who am less than the least of all the saints, this grace was given, that I should preach among the Gentiles .... (Eph 3:8)

Therefore do not be ashamed of the testimony of our Lord, nor of me His prisoner, but share with me in the sufferings for the gospel according to the power of God, who has saved us and called us with a holy calling, not according to our works, but according to His own purpose and grace which was given to us in Christ Jesus before time began, but has now been revealed by the appearing of our Savior Jesus Christ, who has abolished death and brought life and immortality to light through the gospel, to which I was appointed a preacher, an apostle, and a teacher of the Gentiles. (2 Tim 1:811)

Under the inspiration and direction of the Holy Spirit, it is clear that Paul targeted a particular audience, the Gentiles, in his evangelistic efforts.

\section{The Prophet Jonah}

The story of Jonah is fascinating for many reasons, not the least of which is his targeting a specific audience for evangelism under the direction of the Holy Spirit:

Now the word of the Lord came to Jonah the son of Amittai, saying, 'Arise, go to Nineveh, that great city, and cry out against it; for their wickedness has come up before Me.' (Jonah 1:1-2) 
Equally interesting is Jonah's resistance to this leading by the Spirit and the results of that resistance. Jonah decided to set out for Tarshish-the other direction. But God was not willing to let Jonah off that easily, and therefore created a crisis at sea that eventually turned him back to his mission:

But the Lord sent out a great wind on the sea, and there was a mighty tempest on the sea, so that the ship was about to be broken up. Then the mariners were afraid; and every man cried out to his god, and threw the cargo that was in the ship into the sea, to lighten the load. But Jonah had gone down into the lowest parts of the ship, had lain down, and was fast asleep. So the captain came to him, and said to him, "What do you mean, sleeper? Arise, call on your God; perhaps your God will consider us, so that we may not perish." And they said to one another, "Come, let us cast lots, that we may know for whose cause this trouble has come upon us." So they cast lots, and the lot fell on Jonah. Then they said to him, "Please tell us! For whose cause is this trouble upon us? What is your occupation? And where do you come from? What is your country? And of what people are you?" So he said to them, "I am a Hebrew; and I fear the Lord, the God of heaven, who made the sea and the dry land." Then the men were exceedingly afraid, and said to him, "Why have you done this?" For the men knew that he fled from the presence of the Lord, because he had told them. (Jonah 4:1-10)

God had a particular target audience in mind for Jonah's ministry and He saw to it that Jonah went to the specific city of Nineveh to address the Ninevites. The rest of the story tells the result of Jonah's obedience in speaking to the audience God had chosen and Jonah's personal reaction to the result, which was certainly not what Jonah expected:

Now the word of the Lord came to Jonah the second time, saying, "Arise, go to Nineveh, that great city, and preach to it the message that I tell you." So Jonah arose and went to Nineveh, according to the word of the Lord. Now Nineveh was an exceedingly great city, a three-day journey in extent. And Jonah began to enter the city on the first day's walk. Then he cried out and said, "Yet forty days, and Nineveh shall be overthrown!" So the people of Nineveh believed God, proclaimed a fast, and put on sackcloth, from the greatest to the least of them. (Jonah 3:1-5) 


\section{Ninevah a Receptive Audience}

God, through Jonah, targeted what He knew to be a receptive audience.

Receptivity and its linkage to specific times and circumstances is a simple fact, as noted by church growth specialist Donald McGavran:

The receptivity or responsiveness of individuals waxes and wanes. No person is equally ready at all times to follow "the Way." The young person reared in a Christian home is usually more ready to accept Jesus Christ at twelve than at twenty. The skeptic is often more willing to become a disciple after serious illness or loss than he was before. This variability of persons is so well known that it needs no further exposition. ${ }^{1}$

Attempting to identify and capitalize on the receptivity of individuals and groups for the sake of the gospel is a reasonable idea and, ultimately, can have a significant impact on evangelism and church growth. As seen, God Himself sometimes directed individuals to receptive targeted audiences.

It is possible to recognize a change in a specific target audience's receptivity. Such church growth specialists as McGavran have pointed out factors which affect receptivity. Church Growth: America magazine published a receptivity scale, based on the Holmes-Rae stress test developed at the University of Washington Medical School. ${ }^{2}$ Items such as "death of a spouse," "divorce," and "marital separation" are included. Such items may account for the increased receptivity of an individual.

The receptivity of a large group may be along similar lines. Circumstances converge to create a sense of need which may be filled by the gospel. This may well be

${ }^{1}$ Donald A. McGavran, Understanding Church Growth (Grand Rapids, MI: William B. Eerdmans Publishing Company, 1976), 216.

${ }^{2}$ Arn, 143. 
under the direction of God. As Jesus said, "And I, if I am lifted up from the earth, will draw all peoples to Myself" (John 12:32) John 1:9 states of Jesus, "That was the true Light which gives light to every man coming into the world." Ellen White indicates that this drawing influence is the work of the Holy Spirit:

It is through the influence of the Holy Spirit that we are convicted of sin, and feel our need of pardon. None but the contrite are forgiven, but it is the grace of God that makes the heart penitent. ${ }^{1}$

If, as Ellen White suggests, the Holy Spirit is the motivating force behind these ripenings, we should expect to see them often. McGavran again points out:

Sudden ripenings, far from being unusual, are common. No one knows or has counted the ripenings of the last decade, but it is safe to say that they total hundreds. Those which have been effectively harvested are, alas, smaller in number. One wonders why a single one of them should have been lost?

One of these sudden ripenings apparently affected Nineveh. With no indication of receptivity which Jonah could see, God sent him to harvest the ripened grain. The harvest was great enough to save the city from certain destruction.

\section{Jesus}

Jesus told the disciples that part of their job was to harvest the ripened grain which was identified when $\mathrm{He}$, Himself, was involved in targeted evangelism as he moved through Samaria toward Galilee: "He left Judea and departed again to Galilee. But He

${ }^{1}$ Ellen G. White, Selected Messages from the Writings of Ellen $G$. White, vol. 1 (Washington, DC: Review and Herald Publishing Association, 1958), 353.

${ }^{2} \mathrm{McGavran}, 218$. 
needed to go through Samaria. So He came to a city of Samaria which is called Sychar, near the plot of ground that Jacob gave to his son Joseph." (John 4:3-5)

Upon arrival at the well of Jacob, outside Sychar, Jesus sat down to rest while His disciples went into town to buy food. While sitting at the well, Jesus had an encounter which led to His making the following statement to the disciples:

Do you not say, 'There are still four months and then comes the harvest'? Behold, I say to you, lift up your eyes and look at the fields, for they are already white for harvest! And he who reaps receives wages, and gathers fruit for eternal life, that both he who sows and he who reaps may rejoice together. (John 4:35-36)

Morgan suggests that Jesus had a political agenda for His choice of routes from Judea to Galilee. John 4:4 states, "But He needed to go through Samaria." The King James Version, which Morgan cites, says, "And he must needs go through Samaria." According to Morgan:

The "must" may be geographical, but I think it has a deeper note. Instead of taking the road of the Judean, He chose the road they did not take, as a protest against their reason for not taking it, and a protest against their prejudice and pride; and an indication of the inclusiveness of His Messiahship. ${ }^{1}$

It seems clear that Jesus timed His journey through Samaria to approach the Samaritan woman and her townspeople because He knew them to be receptive. He needed to be there at a particular time to meet a particular person who would be responsive to the gospel. He used a route His fellow Jews would avoid, arriving at a time when few would be at the well. Is the Samaritan woman and the town she was from a targeted audience? I believe it is valid to at least consider the possibility. One commentator who reinforces this

${ }^{1}$ G. Campbell Morgan, The Gospel According to John (Westwood, NJ:

Fleming H. Revell Company, n.d.), 71. 
possibility is Raymond Brown, commenting on the same portion of the text Morgan mentions, "And he must needs go through Samaria," emphasizing the word "must:"

This is not a geographical necessity; for, although the main route from Judea to Galilee was through Samaria, if Jesus was in the Jordan valley he could easily have gone north through the valley and then up into Galilee through the Bethshan gap, avoiding Samaria. Elsewhere in the Gospels the expression means that God's will or plan is involved. ${ }^{1}$

Or, as W. Frank Scott says, "We, however, may conclude that this was a necessity of redeeming love." ${ }^{2}$

Ellen White says:

This woman was in an appreciative state of mind. She was ready to receive the noblest revelations; for she was interested in the Scriptures and the Holy Spirit had prepared her mind to receive more light. ... The Spirit of the Lord was working with her. ${ }^{3}$

As Jesus talked with the Samaritan woman, it seems that He had a larger goal

in mind. He knew that this woman would be able to influence others in her community.

His goal was not simply one woman, although that one woman was important, it was

reaching an entire community. John tells us that this was the result:

And many of the Samaritans of that city believed in Him because of the word of the woman who testified, 'He told me all that I ever did.' So when the Samaritans had come to Him, they urged Him to stay with them; and He stayed there two days. And many more believed because of His own word. Then they said to the woman, 'Now we believe, not because of what you said,

'Raymond E. Brown, John (i-xii), Anchor Bible (Garden City, NY: Doubleday, 1966), 169

${ }^{2}$ W. Frank Scott, John, Complete Homiletic Commentary on the New Testament (New York: Funk and Wagnalls Company, n.d.), 113.

${ }^{3}$ Ellen White, The Desire of Ages (Mountain View, CA: Pacific Press Publishing Association, 1940), 190. 
for we ourselves have heard Him and we know that this is indeed the Christ, the Savior of the world.' (John 4:39-42)

While the text does not conclusively state that the reason Jesus chose to travel through Samaria, rather than through the normal hill route that the Jews used, was evangelistic, it seems clear within the context that this is the case. When considered in the light of the other examples cited, the possibility lends credence to the concept of targeted evangelism.

In addition, Jesus Himself stated, on another occasion, that He had a specific target audience in mind among the Jewish people. After choosing the twelve disciples, he sent them out to preach and gave them these specific instructions, "But go rather to the lost sheep of the house of Israel" (Matt 10:6). It is clear that Jesus targeted specific audiences at specific times for specific purposes, as led by the Spirit.

\section{Ellen White's Views on Targeted Evangelism}

Seventh-day Adventists hold a high view of Scripture. Believing that the Bible says what it means, we hold that spiritual gifts are, and should be, active in our day. This includes the gift of prophecy. Two passages illustrate this point:

And He Himself gave some to be apostles, some prophets, some evangelists, and some pastors and teachers, for the equipping of the saints for the work of ministry, for the edifying of the body of Christ. (Eph 4:11-12)

And it shall come to pass afterward that I will pour out My Spirit on all flesh; your sons and your daughters shall prophesy, your old men shall dream dreams, your young men shall see visions. And also on my menservants and on my maidservants I will pour out My Spirit in those days. (Joel 2:28-29) 
The Seventh-day Adventist Church believes that Ellen G. White evidenced the spiritual gift of prophecy during the founding days of our denomination in the $1800 \mathrm{~s}$. Our doctrines hold that her writings speak authoritatively as a commentary on biblical issues, but not in place of Scripture. The Seventh-day Adventist Church, in harmony with her own view, treats her writings as a valuable but clearly "lesser light to lead ... to the greater light"1 of the Bible. Consideration of Ellen White's views carries more weight for Adventists than the writings of general scholars, but are clearly subservient to the greater authority of the biblical prophets. Thus, in a paper such as this, written by a Seventh-day Adventist and addressed-in part-to Adventists, consideration of Ellen White's comments on the topic is normative.

Ellen White had enough to say about evangelism and evangelistic methods that a compilation of over 700 pages was prepared on the topic and entitled: Evangelism. ${ }^{2}$ In addition, the 1962 Comprehensive Index of her writings lists five pages of references to "evangelism," "evangelists," and related topics. ${ }^{3}$ Almost all of these comments deal with public and private evangelistic methods, although a few are directed to specific individuals and situations. Nearly half of those listed under "evangelism" deal with working directly with people groups or types; specifically, residents of cities and of the American South. In

'Ellen G. White, Colporteur Ministry (Mountain View, CA: Pacific Press Publishing Association, 1953), 125.

${ }^{2}$ Ellen G. White, Evangelism (Washington, DC: Review and Herald Publishing Association, 1970).

${ }^{3}$ Ellen G. White Estate, Comprehensive Index of the Writings of Ellen $G$. White (Mountain View, CA: Pacific Press Publishing Association, 1962), 1:939-943. 
addition, the Index lists at least three other sections of interest in the context of targeted evangelism. These are "Neglected Classes," the "Negro," and "Higher Classes."1

Several quotations from White are relevant to the discussion of targeted evangelism. The following are a sampling of those quotations:

In the closing proclamation of the gospel, when special work is to be done for classes of people hitherto neglected, God expects His messengers to take a particular interest in the Jewish people whom they find in all parts of the earth. ${ }^{2}$

We have a work to do for the ministers of other churches. God wants them to be saved. They, like ourselves, can have immortality only through faith and obedience. We must labor for them earnestly that they many obtain it. God wants them to have a part in His special work for this time. He wants them to be among the number who are giving to His household meat in due season. Why should they not be engaged in this work?

Our ministers should seek to come near to the ministers of other denominations. Pray for and with these men, for whom Christ is interceding. A solemn responsibility is theirs. As Christ's messengers we should manifest a deep, earnest interest in these shepherds of the flock. ${ }^{3}$

God calls for earnest, humble workers who will carry the gospel to the higher classes. It is by no casual, accidental touch that the wealthy, world-loving, world-worshiping souls can be drawn to Christ. Decided personal effort must be put forth by men and women imbued with the missionary spirit, those who will not fail nor be discouraged. ${ }^{4}$

I'Ibid., 2:1228-1229, 1878.

${ }^{2}$ Ellen G. White, The Acts of the Apostles (Mountain View, CA: Pacific Press Publishing Association, 1911), 381.

${ }^{3}$ Ellen G. White, Testimonies for the Church (Boise, ID: Pacific Press Publishing Association, 1948), 6:77-78.

${ }^{4}$ Ibid., 6:80. 
The cities of the South are to be worked, and for this work the best talent is to be secured, and that without delay. ${ }^{1}$

For many years the Lord has been keeping before His people the needs of the work among the colored people in the Southern United States. ${ }^{2}$ (The emphasis is mine for this set of quotations.)

In addition, Ellen White urged that special efforts be made to reach young people, a concept remarkably similar to making special efforts to reach Baby Boomers. (One wonders if such efforts had been made in Boomers' formative years whether we would be discussing these issues today.) The following quotations taken from the book Gospel Workers are examples of Mrs. White's comments:

Very much has been lost in the cause of truth by the lack of attention to the spiritual needs of the youth. Ministers of the gospel should form a happy acquaintance with the youth of their congregations. ... There are among us many young men and women who are not ignorant of our faith, yet whose hearts have never been touched by the power of divine grace.

Why should not labor for the youth in our borders be regarded as missionary work of the highest kind? It requires the most delicate tact, the most watchful consideration, the most earnest prayer for heavenly wisdom. ${ }^{3}$

The preceding quotations list particular groups or regions to be targeted for special attention and offer reasons for their being targeted. They also contain a variety of specific strategic suggestions about how the targeting could be made effective. While White is very clear that efforts must be ongoing to reach the general population, she is

'Ibid., 9:214.

${ }^{2}$ Ibid., 9:225.

${ }^{3}$ Ellen G. White, Gospel Workers (Washington, DC: Review and Herald Publishing Association, 1936), 207. 
equally clear that certain groups are to receive special attention-sometimes for special circumstances and times. This is the core principle of targeted evangelism.

\section{The Church-Growth Movement and Targeted Evangelism}

The church-growth movement seeks to use the behavioral sciences to analyze

and promote church growth. ${ }^{1}$ According to Tetsunao Yamamori and E. Leroy Lawson:

These sciences can offer many insights into the expansion of Christianity. They can inform the missionary about the culture and behavior of the people to whom he is sent. The missionary, in his effort to present the gospel, must know the best way to communicate it within that culture. He needs to acquaint himself with the patterns of thinking and behaving prevalent among the people. These patterns are as different as the variety of social units and sub-cultures even within one society. No two groups are receptive to the presentation of the gospel in the same manner because of the differences in their socio-cultural backgrounds. ${ }^{2}$

Donald McGavran developed the concept of the homogeneous unit.

According to him, "The homogeneous unit is simply a section of society in which all the members have some characteristics in common. ${ }^{13}$ The concept behind this principle is that at times certain groups of people will become responsive to the gospel. These groups will respond best in situations which fit them in language, culture, and style. Thus, sending an English-speaking missionary into a Spanish-speaking country makes little sense if Spanishspeaking missionaries are available. In the same way, specific targeted audiences within the

${ }^{1}$ Tetsunao Yamamori and E. Leroy Lawson, Introducing Church Growth: $A$ Textbook in Mission (Cincinnati, OH: New Life Publishing, 1975), 63.

${ }^{2}$ Ibid., 63.

${ }^{3}$ McGavran, 85. 
same country require language, cultural, and stylistic targeting. We recognize this by providing ethnic-group churches, for example.

This "homogeneous unit" concept may help explain the theoretical basis for God's plan of targeting specific groups evangelistically and help us better understand why God has chosen to target groups in the past and present. He wants to reach people where they are, and when and how they are most receptive. According to this principle-and God's activity in Scripture-sometimes people appear to be reached most quickly and effectively in groups by the use of methods, techniques, and approaches which connect with their common interests, experiences, and needs.

According to McGavran's definition, a homogeneous unit has "some characteristics in common." Most often, the term refers to a tribe, a language group, or a cultural group. Examples might be Jews in the United States or Brahmans in India. But, according to McGavran, the homogeneous unit does not have to be so clearly defined: “... the homogeneous unit is an elastic concept, its meaning depending on the context in which it is used. However, it is a useful tool for understanding church growth."1

As will be seen in chapter 3, the similar life experiences of Baby Boomers have formed common characteristics within what demographers call "the generational cohort."2 These common characteristics provide a cohesiveness which identifies Boomers as a homogenous unit. That fact calls for a targeted evangelistic approach designed to take

'Ibid., 86.

${ }^{2}$ Generational cohort is the technical term used by demographers for an age grouping. See Crispell, 9. 
advantage of the unique characteristics of Baby Boomers. Studies of church growth literature suggest that specifically targeted strategies are a far more effective way to reach the Boomer generation, both qualitatively and quantitatively.

In summary, then, the Bible and the writings of Ellen White make it clear that there is a solid theological and theoretical base for targeted evangelism. A careful review of these sources indicates that evangelism appealing to the entire population and evangelism directed at specific targeted audiences are both consistent with the inspired record. In addition, a brief review of church growth literature indicates a similar conclusion. There are moments when a general evangelistic appeal best fits the need of a given context. At other times, however, it is best to target particular individuals or groups. The intentional use of both of these evangelistic options optimizes the opportunity to lead people to Christ.

For the purposes of this study, we can safely conclude that targeting Baby Boomers is a legitimate and theologically supportable method for enhancing the overall spreading of the gospel to the world by God's people. 


\title{
CHAPTER III
}

\section{TARGETING BABY BOOMERS}

In order to target any specific audience for evangelism, the audience must be identified. Enough needs to be understood about the audience to make sure that the target is reached and that the methods employed are the most appropriate. In the following section an attempt is made to clearly define the Baby Boom group as a distinct segment of society.

\section{Defining the Baby Boom Generation}

Robert Bast may provide the simplest way of defining Baby Boomers when he succinctly states, "Those who share birth years from 1946-1964 make up the 'baby boom generation." American Demographics magazine says that Baby Boomers were "born between 1946 and 1964. This is the largest of the U.S. generations in both size and scope."2 Smith and Clurman state, "Born between 1946 and 1964, Baby Boomers are the most populous and influential generation in America."3 It is clear, then, that first and

\author{
${ }^{1}$ Bast, 14. \\ ${ }^{2}$ Crispell, 9. \\ ${ }^{3}$ Smith and Clurman, 9.
}


foremost, Baby Boomers are identified in terms of a specific post-World War II time frame.

On this point, there seems to be universal agreement.

It is necessary, then, to carefully study and analyze the unique aspects of this time period. First, it was a time when thousands of soldiers returned to a war-weary homeland to be reunited with their families and communities, and when a nation began to put itself back in balance after an all-out war effort. The euphoria of this time led to an expected increase in births. What was unexpected was that the trend continued for so long. Anderson explains:

The Population Reference Bureau summarizes the phenomenon this way: "Simply put, the Baby Boom was a 'disturbance' which emanated from a decade-and-a-half-long fertility splurge on the part of American couples. The post-World War II phenomenon upset what had been a century-long decline in the U.S. fertility rate." The decline in fertility after the Baby Boom represents a return to normal more than an exception to the norm. ${ }^{1}$

As will be seen in the next section of this chapter, marketers and others make

the assumption, according to Smith and Clurman, that there are great similarities within the

Baby Boom and other generations.

Members of a generation are linked through the shared life experiences of their formative years-things like pop culture, economic conditions, world events, natural disasters, heros, villains, politics, and technology-experiences that create bonds tying the members of a generation into what social scientists were the first to call "cohorts." Because of these shared experiences, cohorts develop and retain similar values and life skills as they learn what to hold dear and how to go about doing things. This affects everything from savings and sex to a good meal and a new car. ${ }^{2}$

Publishers, 1990), 78.

${ }^{1}$ Leith Anderson, Dying for Change, (Minneapolis, MN: Bethany House

${ }^{2}$ Smith and Clurman, 3, 4 . 
This has led to development of a concept called "generational marketing." In the next section of this chapter, generational marketing will be examined as a means of understanding Baby Boomers in order to develop an evangelistic strategy to reach them. For the purposes of this section of the chapter, it is enough to note that in addition to sharing birth years, Baby Boomers "are linked through the shared life experiences of their formative years." ${ }^{2}$ This linkage has played a major role in the development of the Baby Boom as an identifiable unit.

It cannot be over emphasized that the major factor in the development of the Baby Boom generation is the sheer number of the babies born after World War II. While there is some debate on the exact number of babies born during the boom years, it is clear there were a lot of babies. Gerber explains it this way:

The surge of births that made America temporarily younger was a vivid contrast to the drop-off in procreation that preceded it. Births hit a low of $2,300,000$ in 1933 and did not increase substantially until the beginning of World War II. When the troops came home in 1945, Americans shifted their attention from war plants and battlefields to nurseries and playgrounds. They had more than $3,400,000$ babies in 1946, an increase of 20 percent from the previous year, and the boom was under way. Births peaked at over 4,300,000 in 1957 and stayed above 4,000,000 a year through 1964 . Thereafter the rate gradually rolled off until the beginning of the 1970 s, when it dropped into the 3,100,000-per-year range. ${ }^{3}$

'Ibid., xiii.

${ }^{2}$ Ibid., 3, 4 .

${ }^{3}$ Jerry Gerber and others, Lifetrends: The Future of Baby Boomers and Other Aging Americans (New York: Macmillan Publishing Company, 1989), 13. 
Gerber suggests that there are 75 million Baby Boomers, ${ }^{1}$ while Bast estimates 77 million. That translates to half of all adults in the United States in 1991. No wonder Bast suggests, "The greatest impact of the Baby Boomers came as a result of their sheer number."

The size of the Baby Boom generation is one of the life experiences which has shaped its uniqueness, according to Bast:

As children they heard stories about how the schools and colleges were overcrowded because of them (enrollment in United States schools increased 52 percent between 1950 and 1960); as adolescents they found many of their elders emulating what they wore and dancing to their music; and as adults, their enormous buying power would determine what was "in" for the whole culture. Time magazine, in the 1960's, would even make them its "Man of the Year."

Numbers of Baby Boomers created unique conditions for the generation.

Anderson points out that Boomers are used to standing in line:

When the Boomers first arrived there was a shortage of schools, so many were built; when the Boomers finished public school, there was a surplus of schools. When the first Boomers entered college, they created fierce competition for too few spots, so colleges and universities expanded (many were even founded during this period). After the Boomers graduated, colleges and universities suffered from a shortage of students, and many had to close. When Baby Boomers moved into the job market, unemployment soared. After they had all procured jobs, unemployment dropped. We may expect the same shocking effect when Baby Boomers retire, move into nursing homes, and die. ${ }^{4}$

'Ibid., 3.

${ }^{2}$ Bast, 14, 15, 21.

${ }^{3}$ Ibid., 13.

${ }^{4}$ Anderson, 78, 79. 
Every person is shaped by biological heritage. It is the common history and exposure to unique events, however, which make the Baby Boom generation unique. As stated earlier, generational cohorts are shaped by their shared experiences. Doug Murren explains of Baby Boomers, "Unifying our outlook and attitude is the fact that we all share a common cultural experience." Murren continues:

Most of our generation remember the days of the Berkeley free speech riots and the Kent State shootings by national guardsmen-memories which still bring anger. Psychedelia, Jefferson Airplane, marijuana, Jimi Hendrix, the Rolling Stones and Mustang convertibles all ring familiar to the generation coming of age in that era.

The immortal words of John F. Kennedy, "Ask not what your country can do for you, but what you can do for your country" are etched on the hearts and minds of most Baby Boomers, along with Martin Luther King, Jr.'s dream and the first appearance of the Beatles on the "Ed Sullivan Show."

Undoubtedly, the most common reference point for any Boomer is the assassination of President John F. Kennedy. ${ }^{1}$

Murren provides a list of influences which make Baby Boomers unique, or as he puts it, "so special." This list includes: "absentee fathers;" "extreme affluence;" "the greatest economic expansion in world history;" "less purchasing power than our parents;" "the near-constant threat of nuclear war;" and "television as a significant parenting tool."2 Bast points out that Boomers comprise the most highly educated generation in history.

${ }^{1}$ Doug Murren, The Baby Boomerang: Catching Baby Boomers as They Return to Church (Ventura, CA: Regal Books, 1990), 31, 32. The Kennedy quote, used and footnoted by Murren, is from President Kennedy's January 20, 1961, "Inaugural Address."

${ }^{2}$ Ibid., 32, 33. 
"About half of all Baby Boomers have attended college and approximately one quarter are college graduates."1

Then there was the war in Vietnam The impact of Vietnam on Boomers

cannot be overstated. Robert Bast says:

Probably nothing so crystallized and symbolized a generation as the reaction which most Boomers had to the Vietnam War. ... While they had nothing to do with the decision to wage the war, they were the ones who fought it.... More than a million Baby Boomers saw combat in Vietnam. When the agonizing struggle came to an end, they returned to an America which could not deal with the war, and therefore ignored or rejected the veterans who returned home.... The scars of that war are borne not only by those who fought, but by millions of Baby Boomers who lived for eight years with the sword of the draft hanging over their heads.... Vietnam was devastating to millions. ... The Vietnam war shattered for many the belief in both the moral superiority and the physical power of America. It destroyed faith in leadership and created a permanent distrust of institutions. ${ }^{2}$

The influence of these factors, among many others, created a generation. But

Baby Boomers are far from monolithic in their attitudes and beliefs, despite their common

experiences. As Wade Clark Roof points out:

Certainly, the involvement in drugs, rock-and-roll music, and political activism point to major changes in keeping with the reputation of the sixties as a period of profound cultural change. But we should not overlook the one-half of our population who did not try drugs, the one-third who never attended a rock concert, and the overwhelming $80 \%$ who were not politically active. Many were far less caught up in the counterculture, its controversies and protests, than we tend to think. Once we get beyond the stereotypes that still linger on from that era, we discover a generation growing up in the 1960s and 1970s that was incredibly diverse. ${ }^{3}$

${ }^{1}$ Bast, 18.

${ }^{2}$ Ibid., 40, 41 .

${ }^{3}$ Wade Clark Roof and others, $A$ Generation of Seekers: The Spiritual Journeys of the Baby Boom Generation (New York: HarperCollins Publishers, 1993), 34. 
These are the Boomers: half of the adults in the United States, incredibly

diverse, remarkably similar. One area in which this is illustrated is the area of religious

faith. In his major work on Baby Boomer spirituality, Roof reports:

Members of this generation are asking questions about the meaning of their lives, about what they want for themselves and for their children. They are still exploring, as they did in their growing up; but now they are exploring in new, and, we think, more profound ways. Religious and spiritual themes are surfacing in a rich variety of ways-in Eastern religions, in evangelical and fundamentalist teachings, in mysticism and New Age movements, in Goddess worship and other ancient religious rituals, in the mainline churches and synagogues, in Twelve-Step recovery groups, in concern about the environment, in holistic health, and in personal and social transformation. Many within this generation who dropped out of churches and synagogues years ago are now shopping around for a congregation. They move freely in and out, across religious boundaries; many combine elements from various traditions to create their own personal, tailor-made meaning systems. Choice, so much a part of life for this generation, now expresses itself in dynamic and fluid religious styles. ${ }^{1}$

The choices are not all for organized religion. Baby Boomers are largely

missing from churches all across the nation today. In his 1996 report on the state of the

church, researcher George Barna said:

Church attendance is on a five-year decline. It is presently at its lowest level in at least two decades with just $37 \%$ of adults attending on a given weekend. While levels remain fairly stable for those in their twenties, fifties and sixties, attendance continues to drop substantially among Baby Boomers. Half of them attended weekly church services on a typical weekend back in 1991. Today less than one out of three (31\%) do so. That reflects a loss of some 15 million Boomer church-goers on a typical weekend! ${ }^{2}$

${ }^{1}$ Ibid., 4, 5.

${ }^{2}$ George Barna, "The State of the Church, 1996," The Barna Report 1, no. 2 (1997): 1 . 
In his 1997 report, however, Barna highlights what may be a promising sign of increased recent receptivity among Boomers. He notes that attendance "gains have been steadily increasing since last January ... reaching $43 \%$ in January of this year. ... It seems that the surge can be largely attributed to male Boomers." $\quad$ Even with this increase, well over half of Baby Boomers are missing when church attendance is taken each week. Only time will tell if this is truly a trend toward increased receptivity, or a one-time anomaly in attendance.

Roof contends that Boomers are a "A Generation of Seekers" (he believes this strongly enough to so title his report on Boomer spirituality). Given Barna's statistics, this seeking has not yet translated into a satisfactory level of church attendance. As Roof says, "The concern is to experience life directly, to have an encounter with God or the divine, or simply with nature and other people, without the intervention of inherited beliefs, ideas, and concepts." Thus, institutional religion-church-is not always the first choice for those seeking religious experience. Instead, they seek "spirituality." Roof points out:

Almost all of the people we talked to had an opinion about the difference between being "religious" and being "spiritual." ... To be religious conveys an institutional connotation: to attend worship services, to say mass, to light Hanukkah candles. To be spiritual, in contrast, is more personal and empowering and has to do with the deepest motivations of life. ${ }^{3}$

When religion becomes institutionalized, it risks, as Roof notes, "losing its subjective and experiential qualities, thus becoming ritually dry and unmoving." "It is this

\footnotetext{
'Barna, "Has Revival Begun?' 2, 3.

${ }^{2}$ Roof and others, 67.

${ }^{3}$ Ibid, 76, 77.
} 
latter quality-of seeing, of feeling, of acting, in a unified manner-that many Boomers find missing in organized religion," he continues. ${ }^{1}$

Barna points out that while 72 percent of American adults say they are church members, ${ }^{2}$ only 43 percent were attending church in January, 1997. Among Baby Boomers, only 44 percent are church attenders. ${ }^{3}$

If there are, indeed, 75 million Baby Boomers in the United States, and if only 40 percent to 45 percent of Baby Boomers attend church, there is a huge market of between 30 and 35 million unchurched. It is equally likely that some of the "churched" Boomers may be only nominally connected to their church.

Many issues affect Baby Boomers and their relationship to the church. Some of those issues come out of the shared history which made the Boomers an identifiable group. Other issues have to do with the church's ability to touch the lives of Boomers. These issues must be addressed if the church is to have any hope of reclaiming this generation for God.

\section{Marketing to Baby Boomers: The Challenge of Generational Marketing}

In 1989, Mary, the typical Baby Boomer consumer, was 32 years old, married, and lived in suburbia. She owned two TVs and an eight-year-old car in which she

'Tbid., 78. 1997): 1 .

${ }^{2}$ George Barna, "The Top 100: Part 1," The Barna Report 1 (May/June

${ }^{3}$ Barna, "Has Revival Begun?" 2, 3. 
commuted to her white-collar job where she earned less than $\$ 20,000 .^{1}$ Today, Mary, aged 41, is still the typical Baby Boomer consumer. Discovering what she, her husband Harry, and her fellow Boomer consumers will buy has spawned an industry devoted to generational marketing.

The concept of "generational marketing" began in 1968 over a girdle, according to J. Walker Smith and Ann Clurman, who helped develop the concept:

Florence Skelly was sitting in her office at Daniel Yankelovich, Inc., one morning in 1986 when she picked up the telephone to take a call that would forever change the way marketers think about their customers and their markets. ${ }^{2}$

Skelly was being called by the president of Playtex:

On the other end of Florence's telephone line that day was the president of Playtex telling her that his own wife had thrown away her girdle. She remembers his concern and dismay, as she searched for an answer to the question he put to her: "What does this mean for my business?"3

What Skelly and the Yankelovich company discovered was that while Playtex and other companies were doing fine on the traditional four P's of marketing (Product, Price, Promotion, and Places), they were falling short in keeping up with their clienteles' needs in other respects:

Skelly and her associates began to examine this marketing problem from a different angle. From a generational angle. . . Certainly there had been

'Murren, 28.

${ }^{2}$ Smith and Clurman, xi.

${ }^{3}$ Ibid., xi-xii. 
changes and reversals in consumer behavior before, but nothing as deep and perplexing as the kinds that were starting to occur in the sixties. ${ }^{1}$

As Baby Boomers moved into the marketplace, seismic shifts in buying patterns began to occur. The traditional four $\mathrm{P}$ 's were too restrictive in their understanding of consumer patterns. Something new was needed. Commenting on women, in particular, Smith and Clurman suggest:

Under the influence of a new generation, traditional assumptions about fashion, appearance, and even virtue were undergoing radical transformation. This new generation of women had entered the marketplace with new opinions about what they wanted to wear. What had occurred was not a failure of marketing execution, but rather a shift in the underlying social values that determined how a new generation would respond to marketing efforts.

This new generation had some distinct ideas: Girdles were not comfortable. They were confining. Stodgy. Old-fashioned. Boomers just coming into their own as a power in the marketplace didn't want to wear them. When mothers tried to pass on esoteric girdle knowledge to their daughters, the daughters weren't listening. And in a seismic shift, the new freedoms demanded by the daughters were beginning to influence the buying habits of the mothers. ${ }^{2}$

Skelly's counsel to Playtex suggested new strategies that would appeal to the needs and tastes of a new generation of women. Playtex began producing products tailored to the expectations of the emerging Boomer buying population, no longer using stiff bone stays and rubber. Instead, they turned to "softer, lighter, and more flexible fabrics. ... Playtex's sales snapped back." ${ }^{13}$. This brought to the forefront the issue of "generational marketing."

${ }^{1}$ Ibid., xii.

${ }^{2}$ Tbid., xiii.

${ }^{3}$ Ibid. 
The basic concept behind generational marketing is that "each generation is driven by unique ideas about the lifestyle to which it aspires. And it's these aspirations that determine the ways consumers spend and save their money."1 Generational differences are part of a mix of factors which affect the decisions of the people we approach with the gospel. As Smith and Clurman point out, the first rule of marketing is "know your customer. But in practice, this is hard advice to follow. The most difficult part is getting a handle on exactly what it is about your customer that is most important to know." ${ }^{2}$ They add:

Only by knowing how the consuming motivations of your customers are tied to the underlying values of the generation to which they belong will you be able to tailor your products, services, and communications to their needs, interests, and desires. Applied knowledgeably, this will be a key source of competitive advantage for you. ${ }^{3}$

Generational marketing, then, is knowing enough about the consuming motivations and underlying values of a particular generation so that we may use the best methods to approach members of that generation. Applying this concept to evangelizing Baby Boomers means that we need to know enough about Boomers to use the best methods for reaching them. Just as Playtex could not depend on the traditional "four P" marketing strategies to reach the Boomer market, neither can Christians depend solely on traditional evangelistic methods to reach Boomers.

'Ibid., xiv.

${ }^{2}$ Ibid.

${ }^{3}$ Ibid. 
Yankelovich has developed a tool for "getting a handle on exactly what it is about your customer that is most important to know." Their MONITOR ${ }^{\circledR}$ annual survey "remains the longest running and most complete, continuous tracking study of American values, lifestyles, and buying motivations." ${ }^{11}$ In the Christian sphere, George Barna's annual reports on the state of the church in America ${ }^{2}$ perform a similar service.

Such reports perform an excellent service for the church. The evangelistic task can begin with a solid foundation of knowledge. But even the best general knowledge needs to be localized.

\section{Localizing Generational Marketing}

The terms "Unchurched Harry" and "Unchurched Mary" were created in the 1970s by Bill Hybels, pastor of the Willow Creek Community Church. ${ }^{3}$ Hybels, trying to focus the attention of his church, developed these nicknames to personalize the nonChristians he wanted to reach. In Hybels's setting, Harry and Mary are Baby Boomers.

Rick Warren developed a similar picture of the target audience for Saddleback Community Church in Orange County, California. His "composite profile of the typical unchurched person"4 identifies "Saddleback Sam" and his wife, "Saddleback Samantha."

${ }^{1}$ Ibid., xv.

${ }^{2}$ See The Barna Report newsletter previously cited.

${ }^{3}$ Lee Strobel, Inside the Mind of Unchurched Harry and Mary (Grand Rapids, MI: Zondervan Publishing House, 1993), 13.

${ }^{4}$ Richard Warren. The Purpose Driven Church: Growth Without Compromising Your Message and Your Mission (Grand Rapids, MI: Zondervan Publishing House, 1995), 169. The description of "Saddleback Sam" continues on 170, 
Much research has gone into discovering what Baby Boomers are seeking. Some of that research has been carefully structured by pollsters, like the MONITOR survey; other research has been unscientific, but is nevertheless suggestive and useful. Hybels' approach in starting Willow Creek is typical of the less formal approach. Lynne Hybels explains it this way:

Though the church is Jesus' first love, it has certainly not been loved by contemporary Americans. In the years following 1960 there was a steady and dramatic drop in church attendance. Walking door-to-door throughout Palatine in September of 1975, Bill and several other core leaders tried to find out why. ${ }^{1}$

Willow Creek leaders walked the streets of Palatine, Illinois. "Do you regularly attend a local church?" they would ask. If the reply was, "No," the residents would be asked, "Would you be willing to tell me why you don't?" After analysis of the responses, four primary reasons surfaced: church was irrelevant to daily life; services were lifeless, boring, and predictable; pastors pontificated; and churches were always asking for money. ${ }^{2}$

Through his work in a predominately Boomer church, Pastor Doug Murren identified "nine essential understandings for reaching Baby Boomers:"

Baby Boomers are not belongers. ... Boomers are noninstitutional. ... Boomers are experience oriented. ... Boomers are extremely pragmatic in ... sermon tastes. ... Boomers believe women need to be represented in leadership.... Boomers expect that the contribution of singles will be

171.

${ }^{1}$ Lynne Hybels and Bill Hybels, Rediscovering Church (Grand Rapids, MI: Zondervan Publishing House, 1995), 57.

${ }^{2}$ Ibid., 57, 58. 
celebrated and accepted.... Boomers believe the high level of dysfunctionality needs to be faced.... Boomers will applaud innovation. ... Boomers have a sense of destiny. ${ }^{1}$

Rick Warren came to similar conclusions about Boomers when he established

Saddleback Community Church in Southern California. He discovered "four common complaints about churches":

"Church is boring, especially the sermons. The messages don't relate to my life." This is the complaint I heard the most. It is amazing how churches are able to take the most exciting book in the world and bore people to tears with it. Miraculously they are able to turn bread into stones!

"Church members are unfriendly to visitors. If I go to church I want to feel welcomed without being embarrassed." Many unchurched people told me they felt like the church was a clique. When they didn't know the inside terminology, songs, or rituals, they felt foolish and felt the members were watching them in judgment. The greatest emotion the unchurched feel when they visit a service is fear.

"The church is more interested in money than in me." Due to the highly visible fund-raising efforts of televangelists and other Christian organizations, the unchurched are incredibly sensitive to appeals for money.

"We worry about the quality of the church's child-care. ..." The church must earn the trust of parents.... If you want to reach young couples with children, you must have an excellent program for their children. ${ }^{2}$

Notice the correlation between the lists. Hybels found "services are boring." Warren concludes that the unchurched find "church is boring, especially the sermons. The messages don't relate to my life." Murren states: "Boomers are experience oriented." "Baby Boomers are not belongers. ... Boomers are noninstitutional." Hybels says people felt "church was irrelevant to daily life." "Pontificating pastors" was one of the points

${ }^{1}$ Murren, 37-39.

${ }^{2}$ Warren, 191, 192. 
Hybels found upset people; Murren points out, "Boomers are extremely pragmatic in ... sermon tastes. . . Boomers believe the high level of dysfunctionality needs to be faced." While Murren does not directly address the money issue Hybels and Warren raise, he points out the disillusionment Boomers feel toward institutions, which would logically lead to a discomfort in investing in those institutions. Murren is not alone in his assessment. Robert Bast puts it this way:

An enduring legacy of the 1960s is an anti-institutional bias on the part of the Baby Boom generation. "Americans of all ages lost faith in their institutions and leaders in the 1960's, and have yet to recover [that faith], says Paul Light. Yankelovich points out that "in our preoccupation with self-fulfillment, we have grown recklessly unrealistic in our demands on our institutions." No doubt that is true, but the fact remains that those in the Baby Boom generation are still operating with an anti-institutional bias. ${ }^{1}$

Bast continues, "While all institutions suffer from that negative bias, the church is particularly hard hit."2 This distrust of institutions leads many Boomers to shy away from either attendance or membership. As Rick Warren says:

Understanding the demographics of your community is important, but understanding the culture of your community is even more important. I use the word culture to refer to the lifestyle and mind-set of those who live around your church. The business world uses the term psychographics, which is just a fancy way of referring to people's values, interests, hurts, and fears. Long before businesses became enamored with psychographics, Christian missionaries were identifying the differences between cultures. ... In today's secular environment it is just as important to understand the culture we minister in. We don't have to agree with our culture, but we must understand it. $^{3}$

${ }^{1}$ Bast, 60 .

${ }^{2}$ Tbid., 61.

${ }^{3}$ Warren, 165. 
All of this research is a vital resource in learning how to more effectively reach out to Baby Boomers. The methods used in the projects just examined suggest means of gathering data and how that data may profitably inform Christians trying to reach Baby Boomers for Christ.

\section{Localizing and Personalizing Evangelism}

Someone once said, "All politics is local." At some point in the process, all evangelism becomes local and personal. In order to truly understand the evangelistic target, local information needs to be gathered. Put into context with the more widely reported demographic data available from census and other sources, a clear picture of the potential evangelistic target audience can be gathered. With that clear picture in mind, programs to reach the target audience can be developed. This is the essence of any successful evangelistic strategy.

While Ellen White does not make this exact point, rather pinpointing personal work, that personal work must have a basis in information:

In Christlike sympathy the minister should come close to men individually, and seek to awake their interest in the great things of eternal life. Their hearts may be as hard as the beaten highway, and apparently it may be a useless effort to present the Saviour to them; but while logic may fail to move, and argument be powerless to convince, the love of Christ, revealed in personal ministry, may soften the stony heart, so that the seed of truth can take root. ${ }^{1}$

Knowing the felt needs, that is, the needs an individual identifies as his or her own needs, allows the evangelist to utilize effective methods which address those specific

${ }^{1}$ White, Gospel Workers, 185. 
needs. Elsewhere, Ellen White develops this thought, explaining exactly what is required to touch hearts for Jesus:

Christ's method alone will give true success in reaching the people. The Saviour mingled with men as one who desired their good. He showed His sympathy for them, ministered to their needs, and won their confidence. Then He bade them, "Follow Me."

Christ's method was to come close to the people He wished to reach and develop a personal relationship with them. Phillip Samaan says:

Christ's program was first and foremost people. ... He chose what the Jewish leaders described as "uneducated, common men" (Acts 4:13) to reach the crowds. He invested His time, ideas, and efforts in them, equipping them to do His work. And eventually His personality so molded them that even their critics, who accused them of being ignorant, "recognized that they had been with Jesus" (verse 13). ${ }^{2}$

Bill Hybels explains the concept this way:

Biblical communities remain sensitive and loving toward people outside the faith-but they don't stop there. They get intentional by creating opportunities for spiritual seekers to come to a safe place to hear the dangerous, lifechanging, and eternity-altering message of Christ. The bonus is that these communities get to see the miraculous ways that God revolutionizes human hearts, one person at a time. ${ }^{3}$

Hybels continues:

At Willow Creek we've put all our eggs into the basket of relational evangelism... We instruct and encourage our believers to proactively build

'Ellen G. White, The Ministry of Healing (Mountain View, CA: Pacific Press Publishing Association, 1942), 143.

2Philip G. Samaan, Christ's Way of Reaching People (Hagerstown, MD: Review and Herald Publishing Association, 1990), 34.

${ }^{3}$ Hybels and Hybels, 161. 
relationships with irreligious people for the ultimate purpose of leading them to Christ. ${ }^{1}$

At some point in the process, someone who loves Jesus must come alongside of persons seeking to know Jesus, take them by the hand, and lead them to the Cross. In order to market the church to Unchurched Harry and Mary, we Christians need to get to know them. We need to develop a relationship with them, and then invite them to come meet Jesus. This calls for us to localize and personalize our contact with Boomers if we are to maximize our effectiveness in reaching and winning them to Christ. Generational demographics allow us to find the appropriate means of doing this with Baby Boomers like Harry and Mary.

${ }^{1}$ Tbid., 170. 


\section{CHAPTER IV}

\section{CURRENT SUCCESSFUL APPROACHES TO BABY BOOMERS}

Some churches in North America are successfully targeting Baby Boomers in their area. In this chapter, two of the most successful are examined in order to find principles which may be transferred to other churches and locations. The two churches studied are Willow Creek Community Church and Saddleback Valley Community Church.

\section{The Willow Creek Model}

Willow Creek is an important subject for study because Pastor Bill Hybels has successfully targeted Baby Boomers for the outreach efforts of Willow Creek. As Hybels points out, "A study conducted in the early 1990s shows that the median age of Willow Creek attenders exactly matches the median age of the Baby Boom generation."

\section{Willow Creek's Background}

Located in South Barrington, Illinois, Willow Creek Community Church impacts metropolitan Chicago, drawing members and visitors from the entire metroplex. As Carl George says, "Given its 1993 average weekly worship attendance of some 15,000

'Ibid., 210. 
children and adults, Willow Creek is currently North America's best attended church on a week-by-week basis."1

Bill Hybels, senior pastor of Willow Creek, has been asked, "How big do you expect Willow Creek to grow?" Hybels has replied:

We don't know the answer to that. There are 1.5 million people living within a twenty-minute drive of our campus, and yet we're only reaching one percent of them in a typical weekend service. So there's certainly potential for growth! ${ }^{2}$

Hybels's journey to Willow Creek began during his high-school years. Lynne

Hybels tells the story:

A non-Christian friend approached him one day. "Bill, my life is a wreck. My girlfriend dumped me. I'm drinking way too much. And the funny cigarettes are messing up my mind. I need help. I know you're pretty religious. I wonder if I can come to church with you and get squared away.

Before Bill could catch himself, he said, "Well, sure.""3

That church service was eye-opening to both Bill and his friend. Hybels

"experienced the longest sixty minutes of his life." ${ }^{4}$ Lynne Hybels explains:

It was the first time Bill had attended a traditional church with a genuine, downcast, openhearted unbeliever on his elbow, and it was an unmitigated disaster. Everything that happened was wrong for an unchurched kid. During the prelude, the kid looked as if he were going into shock. The "already convinced," who had grown up on this liturgical diet, were accustomed to ancient hymns "interpreted" by ten-year old flautists or less than proficient

${ }^{1}$ Carl F. George, The Coming Church Revolution: Empowering Leaders for the Future (Grand Rapids, MI. Fleming H. Revell, 1994), 59.

${ }^{2}$ Hybels and Hybels, 208.

${ }^{3}$ Ibid., 31.

${ }^{4}$ Ibid., 31. 
pianists. .. . But it was unlike anything Bill's friend had ever heard in a public setting. "Why aren't people throwing things?" he asked in a bewildered whisper.

From there it went south. ... It went on and on and finally ended. On the way home they talked baseball, girls, school, anything but church. They didn't see one another for three days. Finally Bill tracked the kid down....

"Look, Bill, I'm going to shoot straight. I live on the wild side and you live on the religious side. But in spite of that I've always appreciated the fact that you are normal. ... But what you took me to on Sunday was not normal. I've just been wondering why a normal guy like you goes to a place like that."1

For Hybels this was a defining moment. "The face of his lost high school friend lingered in Bill's mind."2 Another defining moment came when asked to lead a youth Bible study at South Park Church, Park Ridge, Illinois. He called the group "Son City." Lynne Hybels explains what happened:

When Bill first started teaching weekly at Son City, he was so intimidated by the teaching responsibility that he asked a respected Christian leader for advice. "Teach through Berghof's Manual of Christian Doctrine," the man replied. ... Five minutes into the message, he realized the kids were lost. He put his notes away, apologized to the kids, and said, "If you'll come back next week, I promise I'll talk about something that is relevant to your life." From then on he always asked himself, "How does this passage, this biblical truth, this doctrine, relate to daily life?"3

Hybels had learned something. In order to get a hearing, he had to say things in a way so that people would listen. In May 1974, one Son City evening was targeted at the non-Christian friends of the young people in the group. "If the kids would bring their

'Ibid., 31, 32.

${ }^{2}$ Tbid., 32.

${ }^{3}$ Tbid., 33. 
friends, Bill would give the clearest Gospel presentation he could come up with," according

to Lynne Hybels. She continues:

The night came and there were kids hanging out the windows. Nearly six hundred charged up students filled the church auditorium, and everything-from the opening jam (our version of a prelude) to the prayer at the end-was designed just for them. We had great contemporary music, sidesplitting drama, a powerful media presentation, and moving lead-in music. Then Bill walked out in jeans and T-shirt with an open Bible in his hands. "Let me read you the greatest story in the history of the world," he said. "It's about a God-man named Jesus." Then he read the story of the crucifixion and made some brief comments. At the end of the message, he said, "The reason Jesus did what $\mathrm{He}$ did is that $\mathrm{He}$ knows that kids like you have rebelled and sinned against $\mathrm{Him}$, even at your relatively young age. But you still matter to God. So He sent His Son to die in your place. If you'd like to receive Him now, stand to your feet."

So many kids stood that he thought they had misunderstood him, so he had them all sit down. He was so nervous that he barely knew what he was saying, but he did his best to explain the story again. Again they stood up-nearly three hundred kids.

That was the birth of what is now called a "Seeker Service." When Willow

Creek began, Lynne Hybels says, it was formulated around a given: It would provide "a safe and informative place where unchurched people could come to investigate Christianity further."1

\section{Criticisms of Willow Creek}

In 1993, Willow Creek's weekend Seeker Services attracted an average of 15,000 people. ${ }^{2}$ The Seeker Service has become the "front door" into serious Bible

${ }^{1}$ Tbid., 39-41.

${ }^{2}$ George, 59. 
teaching and discipling small groups for many. It has also become a source of controversy, according to Maudlin and Gilbreath, writing in Christianity Today:

What Hybels has been catching recently is the ire of several Christian leaders who question the legitimacy of the seeker-sensitive/megachurch movement-of which Willow Creek is the undisputed prototype. Books such as John MacArthur's Ashamed of the Gospel, Douglas Webster's Selling Jesus, Os Guiness's Dining with the Devil, and John Seel's Evangelical Forfeit all portray the seeker-sensitive movement (and sometimes Willow Creek in particular) as a negative force within the church that needs to be combated. ${ }^{1}$

The overarching concern, common to all the critics, is that seeker-sensitive churches compromise the gospel by tailoring their message to non-Christians; that the use of polished entertainment, feel-good sermons, and marketing techniques subtly alter the gospel that is being communicated. ${ }^{2}$

Within Adventist circles, the criticisms are similar. In Adventists Affirm,

Mervyn Maxwell stated the following of an Adventist Church that he had visited:

Regretfully, I must say that the Adventist service I attended had much more in common with the Willow Creek service than I would have preferred. Both seemed to me like accommodations to market-oriented baby-boomer demands. Every attempt to please the customer. High-tech entertainment. No pleas for money (while I was there, anyway). . . . Helping people feel good about themselves. ${ }^{3}$

Maudlin and Gilbreath asked Hybels, "What are the Biblical marks of a healthy church?" Hybels replied:

One way we describe it is that the church exists for the four-fold purpose of exaltation, evangelism, edification, and social action. Then there's the Acts 2 model, where the first-century church devoted itself to teaching, fellowship,

'Michael G. Maudlin and Edward Gilbreath, "Selling Out the House of God?" Christianity Today, July 18, 1994, 21.

${ }^{2}$ Ibid.

${ }^{3}$ C. Mervyn Maxwell, "Baby Boomers and Moral Leadership," Adventists Affirm, Fall 1991, 9. 
prayer, and Communion. Sometimes we just go down the grids looking for those marks of a Biblical church, then we keep lining Willow Creek up against them to see how we're doing. ${ }^{1}$

"Why do you think the authors of these critical books-all intelligent, respected men-see the seeker church as falling short of these marks?" was the next question they asked. Hybels responded:

First of all, I think there are many people who have observed our methods and have taken them to an unhealthy extreme. That's why, when I'm asked how I feel about the criticisms of the seeker-sensitive movement, I say I appreciate them because they're good for the church. One of my early mentors said to me, "Bill, just remember this: Sometimes your critics are your best critics."2 I thought that was profound.

The second reason I think some of those books come about is my hunch that they are written by men and women who have not spent a lot of time doing evangelism themselves. I wonder if these people have really had a close relationship with a hell-bound man or woman, because they make winning souls sound so clear-cut. To get a hearing for the gospel today, there needs to be personal investment of a Christian into the life of someone outside the body of Christ. These people are looking for a halfway house where they can go and remain anonymous and not have to commit the minute they walk in the door. The seeker movement has grown out of the experiences of those who are in the trenches of personal evangelism every day.

The third thing is that most of these people who have written critiques really don't know us that well. ${ }^{3}$

If culture influences the gospel, the criticism leveled against Willow Creek is valid and troubling. One purpose of the gospel is to influence culture so that members of

'Maudlin and Gilbreath, 22.

${ }^{2} \mathrm{I}$ take this to mean that we need to listen to our critics. They sometimes have something to say which we need to hear.

${ }^{3}$ Tbid. 
the culture come to know Christ and see that lives are transformed by Him. "Secular drift"1 is a danger in all parts of life and to all religious institutions. Whether it is Willow Creek, the local church, or the General Conference, we must guard against secular drift.

At the same time, interaction with the contemporary culture is unavoidable. As

Paul said:

For though I am free from all men, I have made myself a servant to all, that I might win the more; and to the Jews I became as a Jew, that I might win Jews; to those who are under the law, as under the law, that I might win those who are under the law; to those who are without law, as without law (not being without law toward God, but under law toward Christ), that I might win those who are without law; to the weak I became as weak, that I might win the weak. I have become all things to all men, that I might by all means save some. Now this I do for the gospel's sake, that I may be partaker of it with you. (1 Cor 9:19-23.)

If Willow Creek's seeker-service is all that Willow Creek does, then one must agree with the critics: it is not enough. But one can acknowledge that traditional Adventist evangelistic meetings are not enough, nor is a Billy Graham crusade, nor a Revelation Seminar. To bring a person to Christ without challenging her or him to live in Christ is to do only part of our task. Hybels agrees:

We needed to pay attention to both parts of the Great Commission. Yes, we wanted to be a worshiping church, but that doesn't fulfill the evangelistic imperative of Christ's command. Sure, we wanted to reach seekers with the Gospel, but that didn't achieve the 'second directive: to grow up believers in their faith. We needed to do both-and to do it according to the unique thumbprint that the Holy Spirit had in mind for us.

'Jon Paulien, Present Truth in the Real World: The Adventist Struggle to Keep and Share Faith in a Secular Society (Boise, ID: Pacific Press Publishing Association, 1993), 62. "We will call the process by which an Adventist moves from deep commitment to secular detachment 'secular drift'." 
So we developed a clear vision statement: We want to become a biblically functioning community. Then we summarized our mission is one sentence: We want to turn irreligious people into fully devoted followers of Christ. Anything less would not do justice to Jesus' marching orders in the Great Commission. $^{1}$

\section{Successfully Targeting Baby Boomers}

As stated, Willow Creek has successfully targeted Baby Boomers in their outreach efforts. The church's demographics almost "exactly matches the median age of the Baby Boom generation." ${ }^{2}$ Whether or not Willow Creek intentionally set out to find a strategy to reach Boomers-apparently it did not-the strategy is successfully connecting with-and winning-Boomers. Hybels says, "Willow Creek is almost an exact representation of our community's demography, so we are not intentionally homogenous. It's a function of where we are. We want to be inclusive and as integrated as we can possibly be."”

While the Seeker Service is the most visible part of Willow Creek's evangelistic strategy, it is only one part of a seven-step, member-oriented outreach and spiritual-growth cycle. The first step for church members is to build authentic relationships with nonbelievers. Hybels explains:

Today's skeptic isn't likely to pull over and repent at the sight of a Christian bumper sticker. If he's handed a tract, he's probably going to pitch it into the first wastebasket he sees. If he's approached by a stranger, he's going to raise his defenses. But there's credibility in relationships. There's trust. There's a track record of caring and love. And so the typically irreligious individual needs someone who will build an authentic friendship with him, who will

${ }^{1}$ Hybels and Hybels, 169.

${ }^{2}$ Ibid., 210.

${ }^{3}$ Maudlin and Gilbreath, 24. 
answer his questions and sincerely discuss his problems, who will live out his faith before him in a humble and honest way-earn the right to delve into the sensitive topic of faith.

At Willow Creek we've put all our eggs into the basket of relational evangelism. We barely do any advertising, we aren't on television and radio, and we don't use direct mail or visit strangers door-to-door. Other churches may find those approaches helpful, but that's not the thumbprint the Holy Spirit has impressed upon our church.

Through our ... training course, as well as through other teaching and modeling, we instruct and encourage our believers to proactively build relationships with irreligious people for the ultimate purpose of leading them to Christ.

The second step is to share a verbal witness. Hybels continues:

It's not enough to merely enter the world of unbelievers, build relationships with them, and live out our faith in front of them. At some point, if we're praying for them, the Holy Spirit is going to open up a window of evangelistic opportunity, and we've got to know how to respond.

By themselves, these first two steps-building relationships with seekers and being equipped to share your faith-are enough to revitalize a church. ... If people would prayerfully enter into the redemptive drama, their own lives would change, and all of a sudden new Christians would be walking around. And that inevitably softens everybody's heart toward seekers. ${ }^{1}$

The third step is to bring seekers to a service especially designed for them.

Hybels says, "Christians do require help in the evangelistic process." That is Willow

Creek's Seeker Service. The purpose is evangelism targeted at the friends of members who want to know more about becoming a Christian. Hybels says:

Here's the deal we've struck with the Christians at Willow Creek: you build meaningful relationships with irreligious individuals, pray for them and care for them, describe to them how Christ has changed your life, and explain the Gospel as the Holy Spirit opens up the opportunities. And then, as a tool you can use in your personal evangelistic efforts, those in the church who are

${ }^{1}$ Hybels and Hybels, 170-172. 
gifted as musicians and actors, producers and teachers, dancers and vocalists, will knock themselves out to present the basic truths of Christianity in a creative, compelling, and Spirit-anointed way. And together-as a team-we'll reach our community for Christ; one friend, one neighbor, one colleague, one family member, at a time. ${ }^{1}$

The fourth step in Willow Creek's strategy is to regularly attend a service for believers. Willow Creek's "New Community" is a time of extended worship and directed teaching. Says Hybels, "I can shore up a sagging value, talk about a new opportunity, or point out the next hill we're going to take, and we can have confidence that we're handling 'family matters' without boring or confusing seekers." He continues:

We've come to realize that as New Community goes, so goes the church. The hearts of our believers need to be filled to overflowing with love of another kind if they're going to be able to live the compassionate, sacrificial, and authentic Christian lifestyle that will be salt and light to seekers. ${ }^{2}$

The fifth step in the cycle is for new members to join a small group. As Hybels puts it:

Small groups provide the optimal environment for incubating the maturing process. Where there is trust and transparency, and where there are extended periods of time to help each other apply biblical truth to real-life situations, suddenly scriptural truths that seemed theoretical become concrete and practical.

Hybels adds, "We want Willow Creek not to be a church that offers small groups but to become a church of small groups."

${ }^{1}$ Ibid., 173.

${ }^{2}$ Ibid., 176-177.

${ }^{3}$ Ibid., 178. 
The sixth step in the process is to discover, develop, and deploy spiritual gifts.

Hybels explains this step:

At Willow Creek we don't start with a volunteer position that we desperately need to fill ... and then browbeat people into reluctantly agreeing to serve. That's a formula for frustrating the individual and demotivating the church. Instead we start with the person. What spiritual gift has God bestowed on him or her? What kind of passions, temperament, and personality does he or she have? Once that's determined, we try to match the individual with a position in one of our ninety-four ministries that fit him or her well.

The result: people serve with joy and effectiveness, with fulfillment and longevity, and everyone is left marveling at how God created His church as an interconnected, interdependent community in which each person can make a unique contribution. ${ }^{1}$

The seventh and last step in the cycle is to steward resources in a God-

honoring way. Hybels explains the concept:

At Willow Creek we don't employ professional fund-raisers, put thermometers on the wall, or make arm-twisting visits to people's home. We just teach the New Testament value that all we are and all we have belongs to God and that we should honor Him by giving at least the historical ten percent called the tithe.

... we've tried to tell people, "Look, you're in a relationship with a God who loves you irrationally, a God who can be trusted, a God who is very specific about how you ought to handle your money. You ought to avoid debt like the plague. You ought to live within your means. You ought to be frugal and unselfish. And you ought to believe that if you're generous with God's work, He will be generous back to you in ways that go far beyond just dollars and cents.

In the end, financial stewardship isn't a money issue. It's a heart issue. And that's why it's the last of the seven steps. A human heart needs to be transformed before a person's wallet reflects full devotion to God. ${ }^{2}$

${ }^{1}$ Ibid., 179.

${ }^{2}$ Ibid., 180,181 . In the second paragraph of this quotation, Hybels says, "You're in a relationship with a God who loves you irrationally." I understand that to 
Of course, the goal is that they restart the cycle with the formerly irreligious people now transformed into fully devoted followers of Christ reaching out to irreligious people who need to be transformed into fully devoted followers of Christ reaching out to others so that they may enter the cycle.

By teaching members to use the above seven steps, Willow Creek is successfully reaching Baby Boomers and others for Christ, and helping them grow in their Christian experience. Much of what is happening at Willow Creek is worthy of study and adaptation to other situations. Careful consideration should be given to this model of ministry, including the model of evangelism Willow Creek uses.

\section{The Saddleback Model}

Another church that has successfully attracted and evangelized Baby Boomers over the years is Saddleback Valley Community Church. Saddleback is located in the Saddleback Valley area, Mission Viejo, Orange County, California. In 1979, Rick Warren, now senior pastor at Saddleback, was a seminary student at Southwestern Baptist Seminary in Fort Worth, Texas. Following an independent study of the one hundred largest churches in the United States, Warren concluded, "Healthy large churches are led by pastors who have been there a long time." He said:

Knowing the importance of longevity in growing a healthy church I prayed, "Father, I'm willing to go anyplace in the world you want to send me. But I ask for the privilege of investing my entire life in just one location. I don't

mean that God loves unconditionally and will do whatever is required to maintain the relationship, including send His Son to die in our place. See 1 Cor 1:27-30. 
care where you put me, but I'd like to stay wherever it is for the rest of my life."'

Warren then tacked a map of the world on his wall and began praying, with his wife, about where he should go after seminary. He observed, "As we prayed for about six months, God impressed upon us that we were not to serve overseas. Instead, we were to plant a new church in a major metropolitan area of the United States."

I prayed about beginning a church in Detroit, Philadelphia, Chicago, Albuquerque, Phoenix, and Denver. Then I discovered that the three most unchurched states in America were Washington, Oregon, and Califormia. So I narrowed my focus to four areas on the West Coast: Seattle, San Francisco, San Diego, and Orange County. These four metropolitan areas were all growing in the late $1970 \mathrm{~s}$, and that caught my attention. ${ }^{2}$

\section{Saddleback Community Church's Background}

After researching census data and other demographic information, Warren "discovered that the Saddleback Valley in Orange County, Southern California, was the fastest-growing area in the fastest growing County in the United States during the decade of the 1970s."3 Warren wrote to the Southern Baptist Director of Missions for Orange County, Herman Wooten, asking if that area needed churches. Two days later, he received a letter from Wooten asking if he had considered planting a church in the Saddleback Valley. The letters had crossed in the mail.

${ }^{1}$ Warren, 31.

${ }^{2}$ Ibid., 32-33.

${ }^{3}$ Ibid., 34. 
Trips to Orange County and further investigation led to a decision to move from Texas to California and plant what has come to be known as Saddleback Valley Community Church. Warren's first stop was in the real estate office of Don Dale. Warren said to Dale, "My name is Rick Warren. I'm here to start a new church. I need a place to live, but I don't have any money." Warren continued:

Don grinned and laughed out loud. I laughed too. I had no idea what would happen next. Don said, "Well, let's see what we can do." Within two hours Don had found us a condo to rent, got us the first month's rent for free, and agreed to become the first member of Saddleback church! God does provide. ${ }^{1}$

Eventually the church grew from that first member to a church of 10,000 in weekly attendance. ${ }^{2}$ As a first step in establishing the church, Warren felt he needed to know the people he would try to reach. He explained:

In order to understand the mind-set of unchurched southern Californians, I spent the first twelve weeks after moving to the Saddleback Valley going door-to-door talking to people. Even though I knew what these people really needed most was a relationship to Christ, I wanted to listen first to what they thought their most pressing needs were. That's not marketing; it's being polite.

I've learned that most people can't hear until they've first been heard. People don't care how much we know until they know how much we care. Intelligent, caring conversation opens the door for evangelism with unbelievers faster than anything else I've used. It is not the church's task to give people whatever they want or even need. But the fastest way to build a bridge to the unchurched is to express interest in them and show that you understand the problems they are facing. Felt needs, whether real or imaginary, are a starting point for expressing love to people. ${ }^{3}$

'Tbid., 36, 37.

${ }^{2}$ Tbid., 46.

${ }^{3}$ Ibid., 39, 40. 
Saddleback's first public service was Easter Sunday, April 6, 1980. Two hundred and five people showed up at the Laguna Hills High School. Warren described the audience:

It was an unusual assembly for a beginning of a new church. There weren't more than a dozen believers at that first service. Instead, it was filled with unchurched southern Californians. We had hit our target right in the bullseye. ${ }^{1}$

People brought friends who brought friends, and so on. During the first fifteen years of Saddleback's history, the church met in seventy-nine different facilities. "Finally we erected a 2,300-seat high-tech tent. We were filling the tent for four services each week-end before we built our first building,"2 says Warren.

\section{Turning Seekers into Saints}

Warren continues, "Our sanity and survival depended upon developing a workable process to turn seekers into saints." ${ }^{.3}$ Organized around the Great Commandment (Matt 22:37-40) and the Great Commission (Matt 28:19-20), Warren has developed "Five Purposes of the Church." They are: "Love the Lord with all your heart"; "Love your neighbor as yourself"; "Go and make disciples"; Baptizing them"; and "Teaching them to obey." ${ }^{44}$ Warren believed that "unless there is an intentional plan to balance all five

'Tbid., 44.

${ }^{2}$ Ibid., $45-46$.

${ }^{3}$ Tbid., 46.

${ }^{4}$ Ibid., 103-106. 
purposes, most churches will embrace one purpose to the neglect of the others."1 Table 6 (p. 65) shows how this works.

As mentioned in chapter 3, "Saddleback Sam" and "Saddleback Samantha" are symbols of the composite profile Warren developed to identify Saddleback's target audience. Warren describes Sam this way:

Saddleback Sam is the typical unchurched man who lives in our area. His age is late thirties to early forties. He has a college degree and may have an advanced degree. (The Saddleback Valley has one of the highest household education levels in America.) He is married to Saddleback Samantha, and they have two kids, Steve and Sally. ${ }^{2}$

Sam and Samantha are fairly typical Baby Boomers who happen to live in southern California. The description of Sam and Samantha goes on to talk about jobs, debt loads, health consciousness, music, social activities, and religious preferences. As Warren points out, "He's likely to say, 'I believe in Jesus. I just don't like organized religion.' We like to counter this by joking, 'Then you will like Saddleback. We're disorganized preligion."'+3

In a poster provided to illustrate Saddleback's target audience, Sam is pictured holding a cellular telephone and a pager. The following terms are used to describe him: he is "well educated;" he "likes his job;" he "likes where he lives;" "health and fitness are high priorities;" "he'd rather be in a large group than a small one;" "he is skeptical of organized religion;" he "likes contemporary music;" he "thinks he is enjoying life more than he did

\footnotetext{
${ }^{1}$ Ibid., 124.

${ }^{2}$ Ibid., 169.

${ }^{3}$ Ibid., 171.
} 
TABLE 6

EXPLAINING THE CHURCH'S PURPOSE

\begin{tabular}{|c|c|c|c|c|c|c|c|c|}
\hline Purpose & Task & Acts 2:42-47 & Objective & Target & $\begin{array}{l}\text { Life } \\
\text { Component }\end{array}$ & $\begin{array}{l}\text { Basic Human } \\
\text { Need }\end{array}$ & $\begin{array}{l}\text { The Church } \\
\text { Provides }\end{array}$ & $\begin{array}{l}\text { Emotional } \\
\text { Benefit }\end{array}$ \\
\hline Outreach & Evangelize & $\begin{array}{l}\text { “. . added to } \\
\text { their number } \\
\text { daily those who } \\
\text { were being } \\
\text { saved." }\end{array}$ & Mission & Community & My Witness & $\begin{array}{l}\text { Purpose to Live } \\
\text { For }\end{array}$ & $\begin{array}{l}\text { A Focus for } \\
\text { Living }\end{array}$ & Significance \\
\hline Worship & Exalt & $\begin{array}{l}\text { "They devoted } \\
\text { themselves to. . } \\
\text { breaking of } \\
\text { bread and } \\
\text { prayers. . } \\
\text { praising God." }\end{array}$ & Magnify & Crowd & My Worship & $\begin{array}{l}\text { Power to Live } \\
\text { On }\end{array}$ & $\begin{array}{l}\text { A Force for } \\
\text { Living }\end{array}$ & Stimulation \\
\hline Fellowship & Encourage & $\begin{array}{l}\text { “... devoted to } \\
\text { the fellow-ship } \\
\ldots \text { all the } \\
\text { believers were } \\
\text { together } \\
\ldots \text {. they are } \\
\text { together." }\end{array}$ & Membership & Congregation & $\begin{array}{l}\text { My Relation- } \\
\text { ships }\end{array}$ & $\begin{array}{l}\text { People to Live } \\
\text { With }\end{array}$ & $\begin{array}{l}\text { A Family for } \\
\text { Living }\end{array}$ & Support \\
\hline Discipleship & Edify & $\begin{array}{l}\text { "They devoted } \\
\text { themselves to } \\
\text { the apostles' } \\
\text { teaching." }\end{array}$ & Maturity & Committed & My Walk & $\begin{array}{l}\text { Principles to } \\
\text { Live By }\end{array}$ & $\begin{array}{l}\text { A Foundation } \\
\text { for Living }\end{array}$ & Stability \\
\hline Service & Equip & $\begin{array}{l}\text { "They gave to } \\
\text { everyone as they } \\
\text { had need." }\end{array}$ & Ministry & Core & My Work & $\begin{array}{l}\text { Profession to } \\
\text { Live Out }\end{array}$ & $\begin{array}{l}\text { A Function for } \\
\text { Living }\end{array}$ & Self-expression \\
\hline
\end{tabular}

Warren contends that all five aspects of the church's purpose must be in balance for the church to function properly. Adapted from: Richard Warren. The Purpose Driven Church: Growth Without Compromising Your Message and Your Mission (Grand Rapids, MI: Zondervan Publishing House, 1995), 119. 
five years ago;" he is "self-satisfied, even smug, about his station in life;" he "prefers casual and informal;" and he is "overextended in both time and money."

Saddleback Church intentionally targets the Baby Boomers in the Saddleback Valley. Warren put it this way:

For your church to be most effective in evangelism you must decide on a target. Discover what types of people live in your area, which of these groups your church is best equipped to reach, and then discover which styles of evangelism best match your target.

As Warren continued, "The Bible determines our message, but our target determines when, where, and how we communicate it."2

\section{Targeting Baby Boomers}

Saddleback Church targets Baby Boomers in the Saddleback Valley extremely well, with a purpose. Warren explains, "The goal of your church is to move people from the outer circle (low commitment/maturity) to the inner circle (high commitment/ maturity). At Saddleback, we call this 'moving people from the community into the core."'3

Warren uses five concentric circles to illustrate this movement. Figure 1 on the next page shows this concept.

In order to reach the first identified group, the community, Saddleback teaches members to befriend unchurched people. Then, to move people from community to core, Saddleback uses a Seeker Service approach. Says Warren:

\footnotetext{
${ }^{1}$ Tbid., 170.

${ }^{2}$ Ibid., 157.

${ }^{3}$ Ibid., 131.
} 


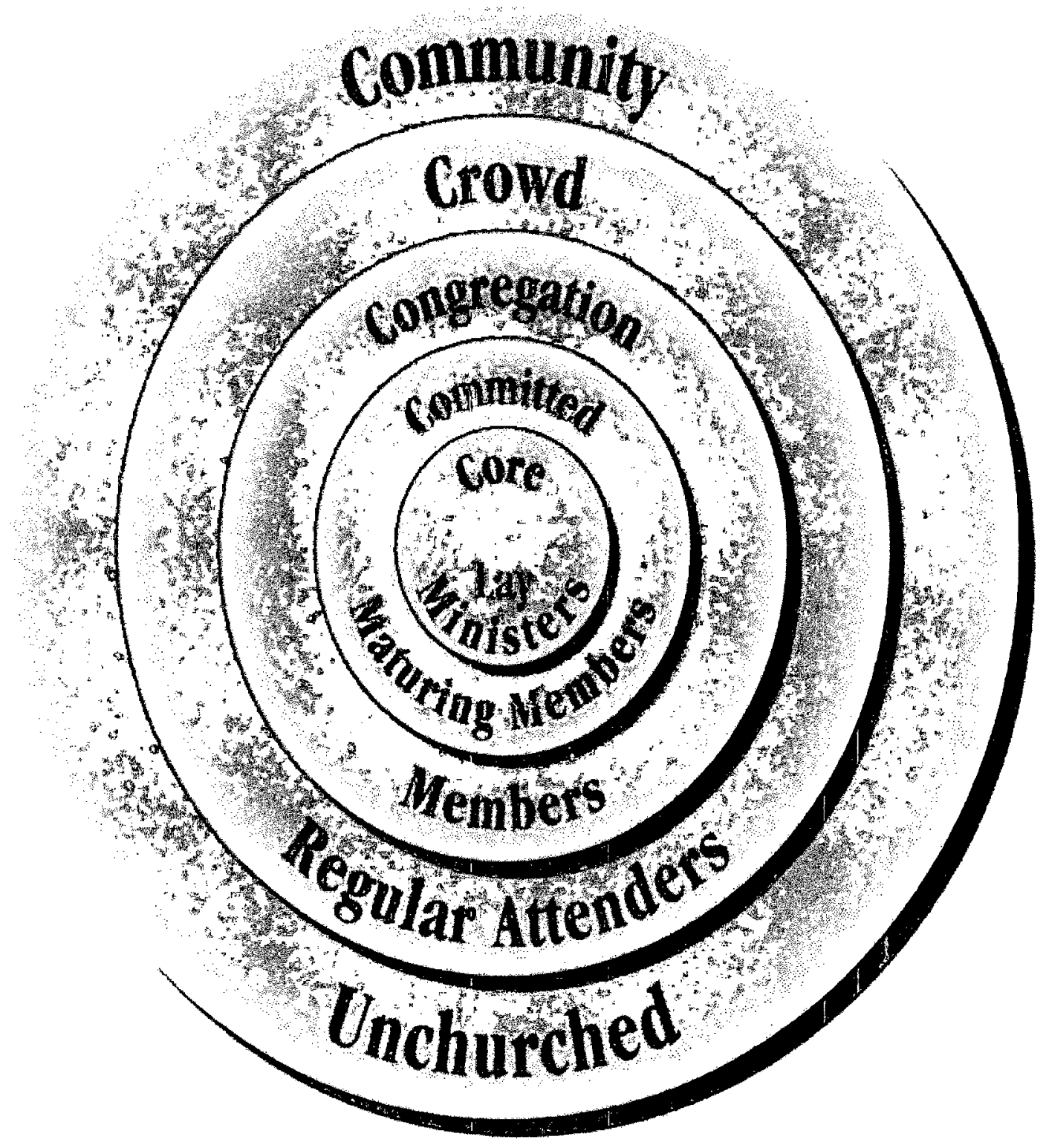

Fig. 1. From Community to Core. The diagram illustrates the movement of unchurched people into a committed relationship with Jesus and involvement in the activities of the church as they move through Saddleback's assimilation program. Source: Richard Warren. The Purpose Driven Church: Growth Without Compromising Your Message and Your Mission (Grand Rapids, MI: Zondervan Publishing House, 1995), 129 ff. 
Increasing the size of your church does not require the intelligence of a rocket scientist: You must simply get more people to visit! No one becomes a church member without first being a visitor. If you only have a few visitors each year, you'll have even fewer new members. A crowd is not a church, but to grow a larger church, you must first attract a crowd.

What is the most natural way to increase the number of visitors to your church? By making members feel guilty for not inviting friends? No. By putting up a big sign that says "Visitors welcome?" No. By cold-calling on homes in your neighborhood? Probably not. By holding attendance contests? Unlikely. By using telemarketing or advertising? Wrong again. ${ }^{\text {' }}$

\section{Transferable Principles from Willow Creek and Saddleback}

The purpose of Saddleback's Seeker Service is the same as Willow Creek's: It is an entry point for the unchurched friends of members. The goal from that point is to turn attenders into members and develop mature members. Much of what Saddleback does is very reminiscent of Willow Creek.

Saddleback Community Church is another example of a church which successfully attracts Baby Boomers.

By carefully analyzing Willow Creek Community Church and Saddleback Valley Community Church, it is possible to identify the common principles used by these churches for reaching Baby Boomers. Such analysis highlights six clear principles: (1) know your target audience, (2) identify and meet felt needs, (3) have a plan for evangelism, (4) involve church members in the plan, (5) have a plan for assimilation, and (6) have a plan for spiritual development. Both Willow Creek and Saddleback follow these six principles.

${ }^{1}$ Ibid., 252, 253. 
It appears that these six principles may be transferable to almost any context and, therefore, are universally applicable.

Let us look at these principles more closely. The first principle is to know your target audience. Both Hybels and Warren spent time getting to know the people they targeted. They went door-to-door in order to gather demographic data and to get to know people. ${ }^{1}$ As Warren said, 'I've learned that most people can't hear until they've first been heard. People don't care how much we know until they know how much we care." Some sort of strategy which allows church leaders and members to get to know the people around them is absolutely essential to an effective evangelistic strategy.

The second principle is to identify and meet felt needs. By talking to members of the community both Hybels and Warren were able to speak directly to issues of concern to people. Thus, when they used the Bible to answer a problem, they were answering a question that people were actually asking within the community.

The third principle is to have a plan for evangelism. Warren and Hybels both have a strategy for presenting the gospel to interested people. Church members bring interested friends to Seeker Services which introduce these friends to Christ. The strategy is clear and easily implemented.

'On p. 56 above, I quoted Bill Hybels as saying, "We don't . . . visit strangers door-to-door." Please note that the context is relational evangelism, not developing demographics. This first principle is about knowing and understanding the community-developing demographics-so door-to-door information gathering would be appropriate. So would a telephone survey or another direct information gathering method.

$$
{ }^{2} \text { Warren, 39, } 40 .
$$


Principle four is to involve the members. As has been stated, both Hybels and Warren depend on the members to bring interested people to Seeker Services. Hybels points out, "At Willow Creek we've put all our eggs into the basket of relational evangelism." Members making friends who come to know Jesus is what this is all about. The fifth principle is to have a plan for assimilation. People who have accepted Christ need to become part of the church. Warren says, "The goal of your church is to move people from the outer circle ... to the inner circle... . We call this "moving people from the community into the core."2

Principle six is to have a plan for spiritual development. As people come to know Christ, they need to learn how to live with Christ. They also need to know how to survive in a church. Having a plan for them to follow in their growth makes good sense. That plan could be called discipling.

In chapter 3, the point was made that generational marketing allows us to know how to reach out to specific age groups in order to identify those seeking to know Jesus and help them come to the cross. The same is true of the principles developed in this chapter. It appears that by combining the concept of generational marketing with the six transferable principles employed by these two churches, which are successfully reaching Baby Boomers, an effective evangelistic strategy for reaching Baby Boomers can be laid out.

${ }^{1}$ Hybels and Hybels, 170.

${ }^{2}$ Warren., 131. 


\section{CHAPTER V}

\section{AN EVANGELISTIC MODEL FOR REACHING BABY BOOMERS}

This chapter reports on the development and implementation of the principles cited in chapters 3 and 4 as applied to Rock Island County, Illinois, and the Moline Seventh-day Adventist Church. Understanding the principles of targeted evangelism and generational marketing allows the church to consciously choose methods and strategies for reaching out to those who do not know Jesus in this county.

\section{Applying Transferable Principles}

The six transferable principles identified in the previous chapter are: (1) know your target audience; (2) identify and meet felt needs; (3) have a plan for evangelism; (4) involve church members in the plan; (5) have a plan for assimilation; and (6) have a plan for spiritual development. The concept of targeting specific responsive population groups and the related study of generational marketing (which deals with how to understand and approach the group in which one is interested) are extensively discussed in chapters 2 and 3 and now-in this chapter-are applied to reaching Baby Boomers in Rock Island County, Illinois.

In order to apply the six principles for effectively reaching Baby Boomers, several tasks need to be accomplished. These include: study of demographic data; 
development of a plan to identify felt needs; development of a plan to meet those needs; development of a plan to move those whose needs are being met into an evangelistic environment; development of a systematic assimilation plan; planning for the continued growth of both new and existing church members; and finding a way to involve new and existing church members in both the planning and the implementation of the strategy.

Like many pastors, over the years I have tried all kinds of evangelistic methods. I have held evangelistic meetings, invited guest evangelists into my churches, and used satellite and seminar evangelistic programs. These methods have had three characteristics in common: They have been oriented to a large group, they have been targeted at general audiences, and they have been only marginally successful.

\section{A Strategy for Reaching Baby Boomers}

An evangelistic strategy was discussed, presented, and adopted by the Moline Seventh-day Adventist Church early in the process of this project. The strategy included the following elements: a prayer offensive including door hangers ${ }^{1}$ asking the community for prayer requests; a community survey; responses to the perceived needs revealed; a Seeker Service targeted at the needs revealed; an assimilation strategy including membership classes, small groups and spiritual gifts classes; and evangelistic meetings approximately every two years. Each element of this strategy was designed to meet one or more of the task requirements needed to follow the principles outlined above.

${ }^{1} \mathrm{~A}$ door hanger is a piece of printed material designed with a cut-out so that the piece may be hung on a door knob. See Appendix B for a sample. 
Development of demographic data was not included in the strategy elements as this had already been done in earlier research for this project. The data was shared with the church as a basis for the strategy. In a recent church election, the church formed an evangelism committee charged with the responsibility of developing and implementing outreach programs and strategies. This paper, through chapter 4 , was shared with the committee as a basis for discussion and planning.

The evangelism committee, meeting every other week over a period of several months, discussed the implementation of various ideas and strategies to reach out to the target population-i.e., Baby Boomers. The committee examined each of the elements listed above, offered suggestions, and made some revisions in details, but accepted the overall plan as a means of moving forward. One of the major concerns the group expressed was how to present the strategy in such a way as to involve the church members personally.

It was finally agreed to present this strategy in a Sabbath sermon setting. I began preaching a series on what it means to be a church. Topics such as worship, fellowship, and outreach were included. As part of the outreach sermon, I presented the strategy targeting Baby Boomers to the church body. (See Appendix A.) Using an overhead transparency, I went through each element of the strategy, explaining what we planned to do and what we hoped to accomplish. At the close of the presentation, I invited the congregation to take the strategy outline home, study it carefully, and plan on discussing it on Sabbath morning two weeks later. 
Two weeks after the initial presentation, I led the congregation in a short worship service, reviewed the strategy which had been presented previously, and opened the floor for discussion. The strategy paper included the following quotation:

Whenever it is possible, let religious services be held on Sunday. Make these meetings intensely interesting. Sing genuine revival hymns, and speak with power and assurance of the Saviour's love. Speak on temperance and on true religious experience. You will thus learn much about how to work, and will reach many souls. ${ }^{1}$

Actually, there was very little discussion. A few questions were raised on the process and on one or two of the elements of the strategy. One parishioner pointed out that the quotation from Testimonies for the Church concerning religious services on Sunday is in a chapter titled "Sunday Labor," dealing specifically with the means of overcoming Sunday laws. She wondered if this quotation was sufficiently out of context as to not apply to Sunday services in other contexts. I shared my conviction that the quotation was applicable to our plan, and that Sunday services could be used to prevent or delay the Sunday legislation discussed in Testimonies.

At the close of the service, I asked for support to carry out the strategy. I specifically asked for prayers and participation in various aspects of the endeavor. Responses seemed favorable at the time, so we began to move forward. In retrospect, it is clear that there was not, and is not today, any strong negative reaction to the concept of targeting Baby Boomers, nor to the various elements of the evangelistic strategy. Neither was there, nor is there now, a sense of ownership and participation in the strategy.

'White, Testimonies for the Church, 9:233. 
The remainder of this report will focus on the elements of the strategy, as they have been developed, implemented, and evaluated in the Moline Seventh-day Adventist Church: the prayer offensive and door hangers, the community survey, the Seeker Service, and satellite evangelism utilizing the Net ' 98 series.

\section{The Prayer Offensive}

The prayer offensive asking the community for prayer requests had a twofold purpose: to serve as a means of finding felt needs in the community, and to serve as a way to involve a large percentage of the congregation in direct outreach to the community. Better than 20 percent of the active church members participated in placing door hangers on four separate occasions during July 1998.

The door hanger used was developed by the North American Division Evangelism Institute, and was widely used in conjunction with Net '98. A sample of the version used here in Moline is included in Appendix B. One side of the hanger invited neighbors to join in praying for their neighbors or to submit a prayer request. The other side quoted Phil 3:6, 7 and identified the Moline Seventh-day Adventist Church as the sponsors of the project. The door hanger was printed on a blue card stock. The stock suggested by the Evangelism Institute was very expensive. We were able to find a local provider for a similar stock at a much lower price. We then imprinted our own information on an inkjet printer.

Church members were invited to remain after a fellowship meal on four Sabbath afternoons to distribute the door hangers in the neighborhood surrounding the 
church. This was promoted in the church bulletin and by the elder making announcements during the church service, and the strategy was mentioned as part of a sermon. During the sermon, I mentioned how I personally did not like knocking on doors, and how I disliked people knocking on my door for this sort of thing. I concluded that hanging cards on door knobs, however, was a non-threatening way to reach out to others, both for the person leaving the door hanger and the resident.

On the first afternoon, after brief instructions and a time of prayer, four groups of four to five individuals placed door hangers on the doors of over 100 homes. Upon completion of their assigned area that same afternoon, each group returned and collected any door hangers which were returned to the doorknobs by residents. The teams then returned to the church to debrief. Most of the door hangers from this initial attempt had not even been removed from the knobs by the time teams got back to pick them up. Only one team picked up a door hanger on which a resident had responded. That solitary response indicated that the person was already involved in her own prayer group.

The teams discussed the lack of response and agreed to revise the plan slightly. It was felt by the group that sufficient time for residents to respond had not been provided. Door hangers would be picked up the next day on a second attempt, rather than just an hour or two later. The wording on the hanger was revised slightly to reflect this change. The next Sabbath, fewer people came out to assist in the project. Again, half a dozen teams went out-this time in teams of two. We had agreed to place the hangers in a spot visible from the street if at all possible. This way, two people in a car could quickly go over the area selected and retrieve any cards on the doors. Again, over 100 door hangers 
were placed. Late the next morning, my wife and I, as agreed by the group, drove through the area, spotted several cards which were on the door knobs, and picked them up. All of these were blank, apparently not removed from the door knobs the previous day. We reported these results to the participants, and discussed the next step.

The area immediately around the church is moderately high income for this area. Houses start in the $\$ 80,000$ to $\$ 90,000$ range, just below the median price range in the Quad Cities. The group wondered if that affected the response rate. On the third trial we moved to a slightly lower income area, still within a half mile of the church. In this area houses start at around $\$ 50,000$. Again, approximately 100 door hangers were left by ten volunteers. Following the same plan for collecting door hangers we had used the previous week, my wife and I drove through the area the next morning. Several door hangers had again not been collected by the residents, but were picked up for review. As on the previous occasion, there were no responses.

We tried one last time. For this trial only six people came out. The results were exactly the same as the previous attempts. There were no responses.

Results from this outreach project were disappointing. Over four hundred door hangers were placed in the community near the church. We tried picking up responses later on the same day and picking up responses the next day. Only one person responded to the door hangers. That response simply said, "I have my own prayer group."

While this strategy failed as a means of gaining contacts or gathering community information, members who participated felt that they had made some impact on the community in that they at least had presented the church as a caring organization. Even 
though we had visited a lower cost housing area with the door hangers, we did not go to the lowest income areas in Moline. This may have had an affect on response. The doorhanger approach to identifying and meeting needs has worked effectively in other areas of the country. Perhaps in another part of Moline it might work as well.

\section{The Community Survey}

The community survey had as its purpose the finding and developing of community felt needs. In seeking approaches to our target audience, we needed to be aware of the interests of those we were targeting. The evangelism committee employed a survey used by Rick Warren ${ }^{1}$ as the basis for the questionnaire that we finally developed for our area. Warren's questionnaire was presented to the evangelism committee for discussion. They suggested some minor changes, which were implemented. After these revisions the questionnaire was reviewed by Dr. Kenneth Stout, committee chair for this project, and Dr. Roger Dudley, Director of the Institute of Church Ministry and Professor of Christian Ministry at Andrews University. Their suggestions were implemented in the final draft. (See Appendix C. The results of the survey, along with the instruction sheet I developed are also included.)

Questions on the survey were open-ended and directed at finding felt needs. They included the following:

1. What do you think are the greatest needs in our community?

2. In your view, how could a church help address these needs?

${ }^{1}$ Warren, 190-191. 
3. Are you actively attending any church?

4. What do you think is the most common reason people don't attend church?

5. What kind of personal services would you expect from a church?

6. By observation the survey takers were asked to indicate the sex and approximate age of those surveyed.

By the time we got ready to do the survey later that fall, I had been sharing the overall strategy with the church for some months. They knew that this was coming, so it was natural to present the survey as a part of a Sabbath sermon. The sermon dealt with how Jesus and the apostles approached and met felt needs before presenting the gospel. It was suggested that, in the same way, we need to know the felt needs of those we approach. I then distributed copies of the survey and an instruction sheet, and showed an overhead transparency of the material. I went through each question on the survey, explaining how this would help us know how to approach various members of our community. I further explained the need for randomness in taking the survey in order to get more accurate results. As an appeal at the end of the worship service, I invited volunteers to take surveys of ten people. I had previously assembled packets of ten surveys each with an instruction sheet. Twenty of these packets were distributed to approximately fifteen members who raised their hands. Some took more than one packet.

These individual volunteers were asked to conduct ten surveys in their own neighborhoods or work places. They were to try to randomize the people they approached; that is, they were not supposed to go only to friends or family, but to try to systematically survey a variety of people. The only stipulation made was that surveyed 
people should be from Rock Island County. Apparently this worked well, as the demographic information recorded follows county demographics fairly well. (See Appendix C.)

While twenty sets of packets had been distributed to approximately fifteen individuals, only four church members returned a total of twenty-eight surveys. I had not noted the names of all those taking survey packets, so was unable to follow up specific individuals. Appeals at the worship service during the next few weeks failed to bring in more survey results. One or two people returned unused packets to me, stating that they were unable or unwilling to conduct the survey. Among the recommendations included in chapter 6 is one for increasing the accountability of volunteers in similar projects.

Some of those taking the survey asked people at work to participate. Others went door-to-door in their neighborhoods. Surveys were turned in over a six-week period. The youth class took one Sabbath School period to do four or five surveys near the church. Most, however, were done during working hours or in the evenings.

A couple of the returned survey sheets were not usable. On those, most of the questions were unanswered, and the questions which were answered had answers which did not address the question. One sheet was nearly indecipherable. It appeared to have been written so hastily that the words could not be distinguished. Since the survey takers did not sign or in any other way identify their returned sheets, this could not be followed up. While the survey responses should be anonymous, in the future I would include a method of identifying the surveyor in order to prevent or mitigate such problems. 
The survey results indicated that a family-oriented approach would be of interest to those in the target audience. Responses to question 1, "What do you think are the greatest needs in our community?" included:

1. Community center activities other than sports

2. More family activities

3. Strong families, safe neighborhoods, jobs

4. Instilling respect in our kids

5. More Christianity

6. Crime Control

7. Family Unity

8. Welfare

9. Teens

10. Peace. Keeping kids on the right road

11. Eliminating drug use and violence, especially among young people

12. Positive role models. Safe place for children in the community

13. Youth of today

14. Teenage morale ${ }^{1}$

Although it cannot be argued that this survey was successful, since the number of completed surveys was not large enough to reflect Rock Island County attitudes with a high degree of accuracy, it did help the church understand some of the felt needs expressed by some Rock Island County Baby Boomers. What surprised me was the fact that family

${ }^{1}$ See Appendix D for more responses to this and other questions. 
issues constituted the major "felt needs" in the returned surveys. According to the returned surveys, programs which target family values and helping families cope should appeal to Baby Boomers and other demographic groups in Rock Island County. Through demographic studies and the community survey we had begun to understand our target audience and the needs they express. This began to meet the criterion of the first two transferable principles developed in chapter 4 . The goal then became developing an evangelistic program to which those in our target audience would come in order to meet their felt needs.

I believe that having volunteers individually distribute the survey may have been a major reason for the limited success of this project. Those who actually did the survey expressed enjoyment in the process and appreciation for the opportunity it afforded to talk to co-workers and neighbors. One person who volunteered to distribute surveys did tell me, "This is not my gift. I feel really uncomfortable knocking on doors." If perhaps, people had been teamed in twos or threes they would have had a greater sense of security in serving as survey takers, and there would have been greater accountability. The fact that many (11 of 15) people did not follow through in presenting the survey to friends or neighbors, or did not turn in their completed surveys, was a serious problem in this program. 


\section{The Seeker Service}

As discussed in chapter 4, a Seeker Service is "a safe and informative place where unchurched people could come to investigate Christianity further." With this in mind, the concept of a Seeker Service was presented first to the elders, followed by a presentation to the church board, and then to the evangelism committee. The concept was finally presented to the church body with apparent good acceptance. Only two or three members questioned the concept in any fashion. There are those in the church who fear becoming what they call a "celebration" church. It was vital that a Seeker Service be approached cautiously to prevent a negative reaction by those with these concerns. ${ }^{2}$

Author Stephen Covey, in his best-selling book, The Seven Habits of Highly Effective People, talks about "paradigm shift," or "what we might call the 'Aha!' experience when someone finally 'sees' the composite picture in another way." 3 Such shifts in thinking may happen quickly or may take great amounts of time.

In describing the sociological phenomenon of change, Ralph Neighbor identifies five types of people who will make up any group. He says:

A new idea seeps slowly through the soil of the total group, moving from one level of persons in the group to the next level. ... There will be some who will see the personal advantages to them very early. Those who do so are called Innovators. The concept will next be accepted by the Early Adopters,

${ }^{1}$ Hybels and Hybels, 41.

${ }^{2}$ See the discussion of these concerns beginning on p. 52 above.

${ }^{3}$ Stephen R. Covey, The Seven Habits of Highly Effective People (New York: Simon and Schuster, 1990), 29. 
followed by the Early Majority, the Late Majority, and perhaps never by the Laggard. ${ }^{1}$

Neighbor points out that Innovators make up only 2.5 percent of any group, Early Adopters 13.5 percent, Early Majority 34 percent, and Late Majority 34 percent. Laggards, who may never buy into a new way of doing things, make up 16 percent of any group. Fully half of any group will resist change, with another 34 percent waiting to see how things go before they get on board.

The biggest challenge in any change process is developing enough support to allow the change to happen. This requires time and consistent presentation of the desired change in a non-threatening manner. Stephen Covey, while writing specifically about negotiation and human interaction, suggests that there are variations on four possible outcomes for the parties involved in change. He says, "The principle of Win/Win is fundamental to success in all our interactions. ..."2

Figure 2 (p 85) shows the options available in developing change. It includes the "Lose/Lose" option, in which all involved lose in the change process; the "Lose/Win" option, in which the change agent loses and others win; the "Win/Lose" option, in which the change agent wins and others lose; and the "Win/Win" option, which is the intended goal. Covey suggests that "high courage and consideration are both essential to Win/Win. It is the balance that is the mark of real maturity."

${ }^{1}$ Ralph W. Neighbor, Jr., Where Do We Go from Here? A Guidebook for Cell Group Churches (Houston, TX: Torch Publication, 1990), 409.

${ }^{2}$ Covey, 216.

${ }^{3}$ Ibid., 219. 


\begin{tabular}{|c|c|c|}
\hline \multirow{2}{*}{ 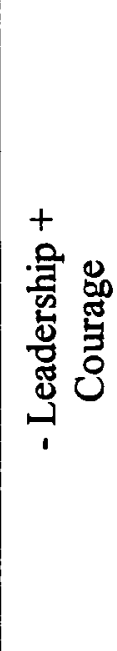 } & $\begin{array}{l}\text { Win-Lose } \\
\text { Transformation efforts can be highly } \\
\text { successful for a while, but often fail } \\
\text { after short-term results become } \\
\text { erratic. }\end{array}$ & $\begin{array}{l}\text { Win-Win } \\
\text { All highly successful transformation } \\
\text { efforts combine good leadership with } \\
\text { good management. }\end{array}$ \\
\hline & $\begin{array}{l}\text { Transformation efforts go nowhere. } \\
\text { Lose-Lose }\end{array}$ & $\begin{array}{l}\text { Short-term results are possible, } \\
\text { especially through cost cutting or } \\
\text { mergers and acquisitions. But real } \\
\text { transformation programs have trouble } \\
\text { getting started and major, long-term } \\
\text { change is rarely achieved. } \\
\text { Lose-Win }\end{array}$ \\
\hline & \multicolumn{2}{|c|}{$\begin{array}{c}\text { - Management + } \\
\text { Consideration }\end{array}$} \\
\hline
\end{tabular}

Fig. 2. Change Results Based on Balance of Leadership/Courage and Management/Consideration. Change results vary with the comparative strength of leadership/courage and management/consideration. When leadership/courage and management/consideration are both strong and balanced (upper right corner) the most successful transformations occur. Neither Kotter's nor Covey's diagrams use this exact terminology, but the concepts are similar. Consider the lower left-hand corner as "Lose/Lose," and the upper right-hand corner as "Win/Win." Adapted from: John P. Kotter, Leading Change (Boston, MA: Harvard Business School Press, 1996), 129 , and Stephen R. Covey, The Seven Habits of Highly Effective People (New York: Simon and Schuster, 1990), 218.

When I came to Moline over three years ago, I set as my first goal to win the trust of the members. I spent the first year making few changes of any kind, and observing how things were traditionally done, so that confidence would be built. The second year was spent making some careful changes, including reworking the order of the worship service and starting to develop some small-group ministries; this set the stage for the evangelistic strategy developed for this project. At the beginning of the third year, the 
evangelistic strategy was presented and the elements tried with varying degrees of success. Now, as I am in the fourth year, corrections in our evangelistic procedures will be made based on what has been learned over the preceding years. (See chapter 6 for discussion of these corrections.)

The key issue in this process is to develop a corporate mentality for the church which focuses on the world outside the church. For most of our members this is a major paradigm shift. Jon Paulien points out the following:

There are churches where the corporate personality is such that it cannot work effectively with secular people. In such cases, those who carry a burden for lost secular people need to form a subculture within the church.

A subculture is a setting in which a particular class of people who belong to the church or are interested in the church but don't quite fit socially or politically can get the spiritual uplift they need. It's a halfway house, if you wish. A subculture aimed at the secular mind-set would intentionally avoid the minor irritations that drive secular people away from churches. ${ }^{1}$

It is necessary, while developing a subculture such as Paulien mentions, to maintain a good working relationship with those who are not part of the subculture-a win/win relationship. The evangelism committee was to serve as the nucleus of this subculture in the Moline church. This was the main reason for proceeding slowly in the implementation of this phase of the project.

As further explanation for the caution I have taken in even attempting a Seeker Service, I would like to share a little Moline Church history. Although these events are public knowledge, they do not get talked about a lot in our church because they are very painful. In the late eighties, the male Pathfinder leader was caught sexually abusing some 
of the boys in the group. The trauma to the affected families and the church at large was enormous. Shortly after this event, there was a pastoral change. The new pastor led in the close of the church's attached elementary school-an unpopular move with many church members-then angered a large portion of the congregation over other matters. His actions nearly split the church.

Another pastor was then placed here, serving several months. Many of the members liked him very much, but unfortunately, he was having marital difficulties which led to his exit from the ministry. I came to Moline against the backdrop of these difficult events.

The point is that these events taught the church how to hurt and how to fight but not how to cooperate. That is why my immediate goal was to model and teach trust, and why I proceeded with extreme caution in even suggesting a Seeker Service.

In late 1998, promotion began for a Seeker Service to begin on Sunday morning, January 2, 1999. Members were urged to invite friends, relatives, and neighbors. No advertising was done, other than providing a simple handout for members to share with those they wanted to invite. The rationale behind this was that the people we could most easily reach were people our members knew. The fact that we had recently used up our evangelism budget for Net '98 (see p 93ff) was a consideration as well.

Again, I used the Sabbath morning service as the main vehicle for promoting the Seeker Service to the members. I talked about what the church was trying to 
accomplish: worship, fellowship, giving, teaching, and evangelism. ${ }^{1}$ I pointed out how two of these objectives might be put together, but cautioned that the more you try to accomplish at the same time, the more difficult it becomes to accomplish any of them effectively. We often try to "do evangelism" during the worship service on Sabbath morning, with limited success. I suggested that what we really needed was a forum for "seekers," i.e., people who want to find out about Christianity for themselves without pressure or the usual trappings of a church service. To that end we planned for a Sunday morning Seeker Service where people could come to find out about Christianity for themselves. As part of the appeal, I asked volunteers to contact me if they would be willing to assist with the program and to prepare children's programming and child care.

The planned format for "Sunday Morning" was simple: a talk on a felt-need topic, and the opportunity to ask questions about the topic or other issues concerning Christianity. No music, no offering, and no hype were included in the plan. ${ }^{2}$ Much of the format was dictated by the lack of enthusiasm I was already feeling from the members. There was no response to the request for volunteers. The evangelism committee and church board had approved the concept of a Seeker Service, but I never felt that there was real support. I did not want to impose on the members so soon after Net '98, and I didn't want to do anything divisive, but despite the lack of member support, I went ahead with the

${ }^{1}$ This is a concept I developed several years ago in trying to understand my own ministry. It has never been published.

${ }^{2}$ The lack of volunteers and my own desire to complete the research on this project led to this decision. In other circumstances I would have included music, drama, multi-media presentations, and group interaction in the plan to overcome Boomer objections to church attendance. See pp. 43, 44. 
Seeker Service for two reasons: (1) a conviction that I needed to try this approach to Baby Boomers in order to determine for myself the effectiveness of this outreach method; and, (2) a hope that even limited success would generate enthusiasm and support among church members.

The plan was for the Seeker Service to meet at the church. This was to keep expenses down and to begin acclimating seekers to the Adventist Church. Again, the purpose of this service was to give seekers the opportunity to explore Christianity. As a Seventh-day Adventist, I believe that part of that exploration should include Christ's injunction to obey His commandments, so I have no problem with inviting people into a Seventh-day Adventist church. It was my intention to say something like this as the opportunity arose:

First we want you to explore Christianity. If that makes sense to you, and if you decide to become a Christian, then we'll need to explore exactly what living in relation to Christ truly means. That's the point at which we'll talk about why Seventh-day Adventists teach the various doctrines they hold.

Table 7 lists the topics and appeals for the planned first six Sunday morning sessions. Early January may not be the best time to begin a new evangelistic venture in Moline, Illinois. Our first session had to be canceled due to a weekend blizzard. The next three weeks were cold, but not unreasonable for January. While I was not surprised by the lack of attendance, due to the weather conditions and my perceptions of the lack of member support for this program, the results were depressing. Not one church member or guest came to any of the programs. I strongly suspect that no guests were invited to attend. A very few members have said, "If it had been July, I would have asked. . . ." 
TABLE 7

SEEKER SERVICE SCHEDULE

\begin{tabular}{|c|c|c|c|}
\hline Date & Title & Topic & Appeal \\
\hline Jan. 9 & $\begin{array}{l}\text { How Your Kids Can Survive in the 21st } \\
\text { Century }\end{array}$ & Parenting & $\begin{array}{l}\text { Relationship } \\
\text { Jesus }\end{array}$ \\
\hline Jan. 16 & Why Sunday Morning? & Program Intro & $\begin{array}{l}\text { Come and bring a } \\
\text { friend }\end{array}$ \\
\hline $\operatorname{Jan} 23$ & Christianity 101 & Meet Jesus & $\begin{array}{l}\text { Come and bring a } \\
\text { friend }\end{array}$ \\
\hline $\operatorname{Jan} 30$ & No program scheduled. & & \\
\hline Feb. 6 & Does Jesus Make a Difference? & Changed lives & $\begin{array}{l}\text { Meet a Bible } \\
\text { counselor }\end{array}$ \\
\hline Feb. 13 & Does Church Make a Difference? & Changed lives & Counselor \\
\hline Feb. 20 & Can You Make a Difference? & Changed lives & Counselor \\
\hline
\end{tabular}

Not only did the weather work against the project, but it seems clear that somehow the church members had not caught the vision of a Seeker Service.

The first topic I planned to present was "How Your Kids Can Survive in the 21st Century." This topic was chosen based on the survey results we had obtained indicating that a family-oriented approach should appeal to Baby Boomers in Rock Island County. I approached the topic with the concept that families could best protect their children from whatever might happen in their lives by helping their children develop a positive attitude about themselves, based on recognition of their relationship to God through Jesus Christ. This would naturally lead to an appeal to "accept Christ in order to help your children build a relationship with Him." 
In my original thinking about the order of presentations, I had planned to use the second topic, "Why Sunday Morning?" for the opening session. This topic was intended to explain what we were trying to do in the Seeker Service: invite those attending to participate by bringing others, and make clear that the whole concept was to invite people to meet Jesus. In addition, I planned to briefly mention that meeting Jesus was only the first step in building a relationship, and that once that step was taken, we would discuss why a Seventh-day Adventist minister would hold a Sunday morning service. I moved this to the second session because of the insight I had gained from the survey results indicating that a family-oriented approach might be appealing to a large number of Baby Boomers.

It was planned that the remaining topics would build on this theme: first and foremost that a person needed to begin a relationship with Jesus, then build that relationship through understanding how Jesus would have us live in relationship with Him and with others.

On January 2, as mentioned, we were snowed out. Sabbath morning, January 8, our members were reminded by a bulletin announcement, an announcement from the front, and a bulletin insert, that the Seeker Service, "Sunday Morning," would meet at 11:00 a.m. the next day. My wife and I were at the church well ahead of time. No one else showed up. I was discouraged, but felt I had to try again, giving those who might have planned to attend another opportunity.

On January 16 and 23, the same procedure was followed. Both Sabbath mornings there were bulletin announcements, announcements from the front, and bulletin inserts urging members to come and bring someone with them. We did not berate the 
members. We simply reminded them of this opportunity to invite people to come meet Jesus in a more neutral setting than a Sabbath morning worship. After the first Sunday morning, I assumed that the weather was the only issue. But on the next two Sunday mornings, with weather not as significant a factor, again no one came. On Sabbath, January 29, I announced that "Sunday Morning" was canceled.

While I did not go to individual church members to ascertain the reasons the Seeker Service initiative failed, I asked the church board members to help me evaluate the program. They suggested that the primary reason was timing. In evangelism, as in comedy, "timing is everything." January does not seem to be the best time for this church to do evangelism. In chapter $1, \mathrm{I}$ noted that our church has a high percentage of older members. These members may not be as eager to get out during cold weather as they were when they were younger. In addition, the severe weather we experienced on the first Sunday morning was seen as a factor. The attitude expressed by board members was not one of relief that the Seeker Service concept had not worked, nor was there any great degree of concern. Instead, the attitude expressed was more along the lines of, "Just one more thing that didn't work." This indifferent attitude must be addressed in any future evangelistic attempt.

I believe that another factor working against this project was the issue of change discussed earlier. This may explain why I feel that there was never any real "ownership" on the part of church members of the Seeker Service concept. A Seeker Service, I believe, was attempting too great a change for the church members to accept. I think that I had moved people from active opposition to neutrality, based on the fact that 
there was no active opposition to the plan. It is clear, due to the lack of member participation, that I had not moved them to support.

Could this approach be used at a later date? Possibly. It would require further efforts to move beyond mere neutrality to active support. It would also require more careful timing. At this stage I am not quite ready to try again.

\section{Satellite Evangelism}

In October 1998, the Moline Church used the Net '98 satellite evangelistic series as an evangelistic outreach to the community. This non-targeted, although billed as "Gen-X friendly,"1 series featured Pastor Dwight Nelson, pastor of the Pioneer Memorial Church at Andrews University, as the evangelist. The series was titled "The NeXt Millennium Seminar." Several elements of the series were geared to appeal to a younger audience than had previous events of this nature. ${ }^{2}$ Hosts chosen for the program were Gen-X'ers. Music was somewhat more lively than that used in previous events. In my opinion, however, Net '98 embodied mostly traditional evangelistic approaches.

\footnotetext{
${ }^{1}$ The following quote is from Glenn Aufderhar and Betty Cooney, How to Hold a Successful Series in Net '98: Pastor's Evangelistic Training Manual Part 2 (Berrien Springs, MI: Net '98, 1998), 30. 'NET' 98 will reflect in its music its special mission to communicate ... to people of all ages." The selection of Dwight Nelson as speaker was an attempt to bring a more contemporary image to the series. Pastor Nelson's messages did that effectively, but the format was still that of a traditional Adventist evangelistic series. I don't believe that technology, in itself, qualifies as the type of innovation expected by most of the Gen-X'ers and Baby Boomers who were seriously looking for a new approach.

${ }^{2}$ Evangelistic series featuring evangelist Mark Finley had been uplinked to satellite in 1995 and 1996. The "NeXt Millennium Seminar" expanded this approach, being beamed to every continent and translated into forty languages.
} 
Our evangelism committee and church board committed several thousand dollars to these meetings, and since it was intended to reach people of "all ages" we felt that we could legitimately include it as a tool to help attain our goal of reaching Baby Boomers. We mailed 30,594 advertising brochures to the two zip codes closest to the Moline church. In addition, members gave 500 or more brochures and personal invitations to friends and acquaintances. We ordered several video invitation packages, which were distributed to church members two weeks before the opening night. These were used, along with handbills, to personally invite friends of members to Net '98.

We had promoted the Net ' 98 meetings in a way similar to the other elements of this overall Baby Boomer outreach project, using bulletin announcements, announcements from the pulpit during the worship time, and personal appeals by the pastor during sermons. In addition, we showed the video invitation mentioned above during the 11:00 hour on the Sabbath we distributed these to members. Enthusiasm seemed to be running high. Church members volunteered to provide children's programming, take care of parking, greet people as they came, take care of registration, and supervise the "book table."

Our opening night attendance was 53, of whom 14 were guests. Of those 14, eight were already attending the Moline church from time to time. We had 39 members and children of members in attendance. This was actually a fairly good response by members, but a poor turnout for guests, given the groundwork done in making sure invitations were given. 
The procedure for each of the five evenings a week while the series ran was for me to welcome the people at 7:00 p.m., then begin a Bible-marking class using Bibles provided at the door. We reviewed the lecture from the preceding session by going through several of the Bible texts which supported Pastor Nelson's presentation. At 7:15 p.m. we joined the downlink for a song service and national announcements. At approximately 7:25 p.m. I made local announcements and again welcomed those in attendance, as some came in after the original welcome. We then rejoined the downlink for the main presentation at 7:30 p.m.

One issue which may have had some effect on opening-night attendance is that the series opened on a Friday night. That particular Friday night was the homecoming football game in both the zip codes we targeted. I doubt that this really had much affect since our attendance was lower on the second night when there was no local football game.

Throughout the series, attendance went steadily down. Some of our members made arrangements to view the meeting via satellite at home. Others simply stopped coming. Still others had pressing reasons for not continuing to attend-illness, business, etc.

Of the guests we had opening night, the ones who had been attending church are still doing so. The other four guests have dropped out completely.

We had no baptisms out of the meetings, but we do expect perhaps five of the eight who had already been attending (i.e., prior to the Net '98 meetings) to join the church during 1999.

Satellite evangelism was included in the strategy to ease the transition to less traditional forms of evangelism for members who are concerned about this issue. 
Additionally, traditional evangelistic approaches provide another contact point for those in the community to learn about Jesus. They also provide a reference point for comparison with non-traditional forms of evangelism. While this approach was not specifically targeted toward Baby Boomers, I had hoped that Pastor Nelson's approach would draw receptive Boomers. It did not, at least in our area. Only one or two of the guests who were already attending our church, but were not yet members, were Baby Boomers.

It seems clear that the church members in Moline continue to be more supportive of traditional forms of evangelism than more experimental methods. It has been some years since the Moline church has hosted a live evangelistic series. This seems to be an outreach method in which the church members feel comfortable participating, and should, therefore, be more successful in reaching the general population around us. While this approach might not target Baby Boomers, Boomers might be among those reached. Taking a family-oriented approach to the series might increase the appeal to Boomers and, therefore, needs to be considered.

\section{Summary of Project Results}

While it is clear that the Moline Church will support traditional evangelism financially, it is equally clear that there is essentially no support, at this time, for nontraditional types of outreach (such as the Seeker Service), and that personal support for these innovative types of evangelism is not strong. The Net ' 98 evangelistic outreach was the best attended by the membership of all the strategy elements. It also drew the largest participation by community members, although this was minimat-and was not sustained. 
Efforts to reach out in a personal way to the community, especially Baby Boomers in the community, have not been noticeably successful.

Whenever a project does not work as desired, careful analysis needs to be made to determine what went wrong. It is clear that several factors contributed to the failure of this project. These include: (1) timing, (2) the general age of the Moline congregation, (3) the need to move church members from resistance to acceptance and, finally, to participation, (4) a general lack of urgency seen in many churches today, and (5) a recent lack of converts from other evangelistic efforts.

Some of the elements of this project were poorly timed for the church. The Seeker Service, in particular, fell at the worst possible time, as far as weather was concerned, with the first session canceled due to blizzard conditions, and ongoing attendance negated by continuing cold. It also followed too closely on the heels of the Net '98 meetings, which also was a demanding endeavor for the church family.

Net ' 98 may have been poorly timed for this community. One can seldom be sure of exact factors, but mid-fall does not seem to be a good time for major evangelistic outreach in Rock Island County, due to an emphasis on and strong community involvement with high-school football.

The older age of the Moline congregation, in my view, was also a factor contributing to the failure of the overall strategy. Several members are no longer able to drive at night. Others do not come out in cold weather. The "homogeneous unit" concept suggests that this predominately older congregation may not be able to effectively relate to 
Baby Boomers. These are understandable and predictable issues which generally decrease support for church initiatives.

It is also important to differentiate between acceptance and support.

Acceptance gives approval for you to do a thing. Support involves active participation by others in doing whatever it is that one is doing. In hindsight, it is clear that the church membership accepted some of the elements of the strategy but did not support them. Resistance had been overcome, but more than acceptance is needed for a strategy such as this to succeed.

At the root, all of these point to the concept of "urgency." Business writer John Kotter explains an eight-stage process for creating change in an organization. The first step in this process is, "Establishing a sense of urgency." A lack of urgency is, I believe, the primary issue facing the Moline church. While this project did not specifically address this issue, it is one which needed to be addressed-and must be-before any future evangelistic outreach is undertaken or, for that matter, for any major project.

The results of this lack of urgency was a lack of support for evangelism. Yet the desperate need for urgency is all around us. George Barna notes that 2.2 million people die each year in America. As he says:

Only God knows how many of those people who die will wind up in a state of eternal separation from God. ... Research suggests ... more than 1 million. ... We have no time to waste. We cannot know when the end of the human

Press, 1996), 21.

${ }^{1}$ John P. Kotter, Leading Change (Boston, MA: Harvard Business School 
age will arrive, nor when any particular person with whom we have contact will die. Time is of the essence. ${ }^{1}$

Finding a means to develop this sense of urgency as a general condition in the church is the most crucial area in which this project has broken down. Other deficiencies were an outgrowth of this fundamental problem. Churches which are successfully targeting Baby Boomers have managed to create a powerful sense of urgency and to mobilize members to respond to it. While they do not explicitly state this as a goal in their writings, Bill Hybels, Rick Warren, and others have gotten across to their members that evangelism is a day-by-day lifestyle dynamic, not a program put on by a professional. ${ }^{2}$ Individual members act on their sense of urgency to bring people to Christ and that is why their churches are growing.

In concluding this chapter detailing the project undertaken and the results, I feel a confession is in order. This whole project has been self-revelatory in bringing to the surface my own struggle with urgency. This personal need for a greater sense of urgency has made it difficult for me to effectively nurture a sense of urgency among the church members. It is easy to say that the creation of urgency really should be the work of the Holy Spirit. It is also easy to point to Rev 3:14-22 (the church of Laodicea) to show that a lack of urgency is common and even, perhaps, to be expected. However, the Laodicean passage also provides what many Seventh-day Adventists, including myself, believe to be

'Barna, Evangelism That Works: How to Reach Changing Generations with the Unchanging Gospel (Ventura, CA: Regal Books, 1995), 11, 17.

${ }^{2}$ For instance, see Bill Hybels' statement on relational evangelism, quoted on p. 57, or Rick Warren's statement on increasing the size of your church, p. 68. 
the only remedy-a renewed commitment to a strong relationship with Jesus, as indicated in the following verses:

I counsel you to buy from Me gold refined in the fire, that you may be rich; and white garments, that you may be clothed, that the shame of your nakedness may not be revealed; and anoint your eyes with eye salve, that you may see. As many as I love, I rebuke and chasten. Therefore be zealous and repent. Behold, I stand at the door and knock. If anyone hears My voice and opens the door, I will come in to him and dine with him, and he with Me. To him who overcomes I will grant to sit with Me on My throne, as I also overcame and sat down with My Father on His throne. (Rev 3:18-21)

Opening the door to Christ and His personal divine urgency is a large part of what ministry is all about. Finding out how to incorporate this as a part of my own life is, I believe, one of the major keys to developing the same urgency in my church.

Chapter 6 concludes this report by reviewing the results of the research and the project, summarizing what has been learned from the overall experience, and suggesting some approaches for the future. 


\section{CHAPTER VI}

\section{SUMMARY, CONCLUSIONS, AND RECOMMENDATIONS}

This chapter summarizes what I have learned from this project, looks at what I would do differently, and suggests possible avenues of future study.

\section{Summary}

It is clear that there is a distinct sub-group in the United States who were born between 1946 and 1964. Demographers identify this group as "Baby Boomers." The size of this group and the shared journey of the group's lives have developed a marked homogeneity. It is equally clear that many Baby Boomers have generally opted out of all forms of organized religion. A strategy to reach this large group is justified.

Biblical evidence, church-growth literature, and other literature also justify a strategy to reach particular receptive groups. This theological perspective requires targeting specific groups for evangelism, and using methods that are tailored to that group. This means that it is fully appropriate-and even important-to target Baby Boomers as part of a balanced evangelistic outreach.

The business world has already discovered the concept of targeting particular groups by age. This concept is called "generational marketing." Concepts developed for and by the marketing industry can legitimately be applied to evangelism. Some churches 
are already applying these marketing strategies successfully. Two examples are Willow Creek Community Church and Saddleback Valley Community Church.

As I have studied the concepts used by these successful ministries and sought to apply them, I have developed six transferable principles for successfully targeting and evangelizing all groups-including Baby Boomers: (1) know your target audience, (2) identify and meet their felt needs, (3) have a plan for evangelism, (4) involve church members in the plan, (5) have a plan for assimilation, and (6) have a plan for spiritual development. It appears that these six principles may be transferable to almost any context and, therefore, are universally applicable. This project applied the principles to work with Baby Boomers.

I developed the following strategy to apply these principles in my local situation: (1) a prayer offensive inchuding door hangers asking the community for prayer requests; (2) a community survey seeking to identify felt needs; (3) a Seeker Service targeted at the needs revealed; (4) an assimilation strategy including membership classes, small groups, and spiritual gifts classes; and (5) evangelistic meetings approximately every two years. This strategy was presented to the Moline Seventh-day Adventist Church and used in evangelistic outreach. This report deals with the implementation of the following elements: (1) the prayer offensive and door hangers, (2) the community survey, (3) the Seeker Service, and (4) satellite evangelism utilizing the Net ' 98 series.

Elements of the strategy met with varying degrees of success from none at all to slight. The main findings from the implementation of the strategy in Moline are as follows: first, door hangers for the prayer offensive did not work well in our community, 
although this part of the strategy did involve a good percentage of church members. Second, the community survey was not successful, in that few church members got involved and only a few questionnaires were returned. Those surveys which were returned may indicate some possible future directions for the church. Third, the Seeker Service suffered from poor timing and lack of involvement by church members. This was the most disappointing element of the strategy to me, personally. Finally, Net ' 98 was moderately successful in involving church members but failed to reach Baby Boomers in any significant way.

\section{Conclusions}

While there have been many lessons learned from this project, there are four areas I feel have impacted me the most. First, I have learned a great deal about Baby Boomers. When I began this project, I thought I understood quite a bit about Boomers. Much of that feeling came from my own experience as a Baby Boomer. I have learned that the Baby Boom generation is exceptionally complex, but that certain generalizations based on solid research can be made. The most important ones, from an evangelism standpoint, are: (1) the need for solid relationships; (2) the tendency to distrust institutions, and (3) the hunger for spirituality. Properly applied, it would seem that these three factors can be utilized to draw Baby Boomers to Christ. Churches which have developed a culture emphasizing personal relationships of members with seekers, especially Baby Boomers, are

growing. The church and its services become a tool used by members to introduce seekers to Christ. This approach meets Baby Boomer needs for relationships, instills trust in the 
relationship rather than in the institution, and provides a spiritual outlet for spiritually hungry Baby Boomers.

Second, I have come to the conclusion that the science, or possibly art, of marketing is something that the church needs to understand much better. I hear Baby Boomers and Gen-X'ers saying. "They don't understand." By “they," Boomers mean church leadership, usually of previous generations. Those saying this are right. "They" often do not understand. Times, circumstances, and people change. Issues and needs are different from generation to generation for a great number of reasons. It is true that basic needs are the same for each generation, as Abraham Maslow ${ }^{1}$ has pointed out. Every Christian knows that what is really needed is a relationship with Jesus Christ. The marketing issue for the church is this: How does one approach differing individuals and groups in order to present Jesus in an appealing and effective way?

Understanding generational marketing, making use of the tools available, and developing approaches to people based on good research are necessities in today's fastpaced world. As a church, we need to be more effective in reaching people for Jesus. Generational marketing is one means of reaching this goal.

Third, I need to work at being a more skilled change agent. As I mentioned in Chapter Five, John Kotter lists eight stages in creating organizational change. These are:

1. Establishing a Sense of Urgency

2. Creating the Guiding Coalition

${ }^{1}$ Abraham H. Maslow, Motivation and Personality (New York: Harper and Row, 1970), 35-58. Maslow's hierarchy of needs include: physiological, safety, belongingness and love, esteem, and self-actualization. 
3. Developing a Vision and Strategy

4. Communicating the Change Vision

5. Empowering Broad-Based Action

6. Generating Short-Term Wins

7. Consolidating Gains and Producing More Change

8. Anchoring New Approaches in the Culture. ${ }^{1}$

As I examine my personal style, I find that I am pretty good at step three. I was able, also, to move people from opposition to acceptance, but not active participation, partially completing step four. Most of the time, however, I do not consider the other six. I suspect that I am not alone. No wonder change is so difficult in the church.

Organizationally we need to teach our pastors how to be effective change agents. Change, on an individual and corporate basis, is what Christian ministry is all about. Utilizing the gifts of the Holy Spirit under His direction, we urge people to change. Understanding the change process helps us bring about change in individuals and groups.

Personally, I need to learn these same things and make use of them in my life and ministry. The only way I will become effective in reaching Baby Boomers for Christ is to develop the personal and corporate approaches which work. This requires change. That means I have to become a more effective change agent.

Fourth, I need to rekindle my own sense of urgency about the soon return of Jesus. In 1979, I wrote a paper for Dr. Mervyn Maxwell comparing church growth 
between Seventh Day Baptists and Seventh-day Adventists. ${ }^{1}$ In that paper, I coined the term "eschatological urgency." I used this term to explain why Adventists were, and are, a strongly proselytizing movement while Seventh Day Baptists resisted proselytizing, concentrating on teaching other denominations to keep the Sabbath. By "eschatological urgency," I meant a drive to tell others that Jesus will come soon, and to help them prepare for that eventuality. I showed that Seventh-day Adventists had grown from approximately 6,000 members in the 1870 s to $6,000,000$ in the 1970 s (in 1999 , that membership figure is over $10,000,000$.) Seventh Day Baptists were approximately the same size in the 1870 s, while their 1970s membership had not grown, remaining in the 6,000-member range. I pointed out that if Seventh-day Adventists ever lost their "eschatological urgency," they would also stop growing.

As I examine my own conscience, I find that this is an issue I need to deal with. I have gotten comfortable here. I need to remember that this world in not my home.

This idea of "eschatological urgency" is what I mean by a sense of urgency. This is what needs to be a part of the vision which drives evangelism in Moline and the Seventh-day Adventist Church at large. When we have this sense of urgency, we will reach out to those around us. We will find and develop marketing tools to understand and reach every segment of society.

${ }^{1}$ Clarence Henry Small, "Why Aren't Seventh Day Baptists Growing? A Comparative Study of Two Sabbathkeeping Bodies," paper for the classes "History of Religion" and "History of the Sabbath," Seventh-day Adventist Theological Seminary, Andrews University, 1979. 
I have asked myself repeatedly how this sense of urgency is rekindled and where it must begin. I found my answer in the first chapter of the book of Acts. "These all continued with one accord in prayer and supplication..." Acts 1:14 Every revival I've ever heard of began with prayer. Every revival I've ever heard of began with one or two people, ten or twelve people, alone, praying. At every level of the church, from individuals to denominational entities, we need to begin praying for the power of the Holy Spirit to give us the urgency we lack.

The conclusions I have reached, based on the research and experience engendered by this project, include the following: first, the research is clear; we can reach out to Baby Boomers using non-traditional approaches. As just mentioned, doing so will require a strong sense of the urgency of this task and the development of the tools and resources needed to carry out the task. The concepts of marketing can help in this endeavor. Generational marketing can be especially helpful in reaching Baby Boomers.

Second, the key to reaching younger generations, including Baby Boomers, is building personal relationships. Growing churches have developed a culture which emphasizes relational approaches to those seeking to know more about Christianity. By building relationships with others, we win their trust enough to introduce them to Jesus.

Third, moving from our traditional models of evangelism to more nontraditional, more relationship-based models is very difficult for churches steeped in the traditional mold. This change requires a major shift in both attitudes and actions. Understanding the process for developing institutional change becomes mandatory for pastors who seek to use non-traditional approaches. 
Fourth, if our churches are going to grow, church leaders at every level-lay leaders, pastors, and denominational administrators-need to begin the transition process mentioned above. The Public Broadcasting System in the United States is airing a series of commercials which asks, "If PBS doesn't do it, who will?" That is a great question for pastors and congregations. If we do not reach out to our community with the urgency of the second coming, who will? If we do not help our neighbors get ready for Jesus to come, who will? Pastors and congregations need to transition to an approach which emphasizes relational- and needs-based evangelism targeted at the people in our communities. In many communities the largest identifiable segment of the population is Baby Boomers. Making the transition to the approach suggested must take that into consideration.

The goals with which I began this project included: (1) finding a means of reaching out, evangelistically, to the unchurched Baby Boomer population in Rock Island County; (2) finding a means of reaching out to Baby Boomers who have dropped out of the Adventist and other Christian churches; (3) increasing the number of Baby Boomer leaders in the Moline Seventh-day Adventist Church; and (4) fulfilling my passion to reach out to unchurched Baby Boomers, thus developing and refining my skills and knowledge in the areas of evangelism and pastoral ministry. (See chapter one.)

The strategy I developed and used with the Moline church did not reach the first three of these goals. I do feel that the knowledge I have gained and the experiences I have undergone in implementing this project have developed and refined my personal skills and knowledge in both evangelism and pastoral ministry. 


\section{Recommendations}

As I have considered recommendations for further development and study based on this project, several things stand out. The first is that a project such as I have undertaken needs a much longer time frame than I have allowed. Instead of a one- to twoyear time frame, a project like this probably needs to be viewed as a five- to ten-year project. As Rick Warren stated, "Healthy, large churches are led by pastors who have been there a long time." Pastors with a vision for growth need time to understand the community in which they are working, develop a sense of urgency in the congregation, and follow through on the change sequence mentioned earlier.

I have noted above that several writers suggest that making these kinds of changes is nearly impossible in an existing church. I still believe the changes can be made, but I have become convinced that this is a major undertaking. Not every pastor nor every church will be willing to go through this process. Some churches may simply require a pastor to help them maintain what they have. Some pastors may be very comfortable in that role. Such churches and pastors should be matched up.

It is also admittedly easier to develop in a newly planted church the relational culture needed to do evangelism in our day. There is no need to change an existing culture in such an environment. Instead, a relational style can be instituted from the beginning.

The second recommendation I would make is for further study of the relationship between the marketing world and evangelism. I believe that we do too many things which are not based on solid research. We do them because we have done them that

${ }^{1}$ Warren, 31. 
way before, or because they feel right, or because we believe that what we are trying will work. A better way to marry marketing and evangelism must be found. I would like to see Christian colleges and universities which have marketing programs find ways to research evangelistic approaches from a marketing viewpoint. I believe this would be a step in the right direction. Having people who have marketing backgrounds helping me in this study would have been a great advantage.

The third recommendation I would make is to develop stronger systems to ascertain volunteer accountability. Pastors need to understand this accountability and be trained in methods of maintaining volunteer accountability for members involved in church projects. While I have done some reading in this area, I recognize that this is something I don't understand. Perhaps persons who work regularly with volunteers (for instance, in social service agencies) could instruct pastors in how to develop these systems.

The fourth recommendation I have is a spiritual one. I am convinced that in my personal life and in the corporate life of the Seventh-day Adventist Church, there is a real need for revival. As Dennis Kinlaw puts it: "The Spirit of the Lord within us can reach someone else with the gospel far more effectively than we can reach that person in our own persuasive eloquence." I long for the day when our denominational leaders will lead revival, our pastors will preach revival, and our members will find revival. I know that this has to begin with me. I hope that it will also begin with each person reading this paper. When revival happens, I believe many of the issues I have identified and dealt with in this

\footnotetext{
'Dennis F. Kinlaw, Preaching in the Spirit (Grand Rapids, MI: Francis Asbury Press, 1985), 18.
} 
paper will no longer be problems. Instead, we will see people developing life-changing relationships with their friends and neighbors.

It is my hope that this research will trigger a greater willingness to try new ideas in the minds of readers on how to reach out to those people whom God lays on their hearts and that some readers will develop a burden for specific societal groups-including Baby Boomers-which can be targeted for gospel evangelism. I also hope that others will work on creating a means by which people can be brought to experience a higher level of "urgency" and "motivation" when they are initially lacking it. Thus, we will see people groups-like Baby Boomers-coming to know Jesus and we will see His soon return. 


\section{APPENDIX A \\ MOLINE SEVENTH-DAY ADVENTIST CHURCH \\ EVANGELISTIC STRATEGY}

- Pray for our community

- 10 block radius

- Walk the streets praying

- $\quad$ Pray in groups

- Pray individually

- If you like, an assigned prayer area

- Pray for individuals

Door hangers

- Requests

- Personal contacts

Questionnaire

- What do you think is the greatest need in this area?

- Are you actively attending any church?

- Why do you think most people don't attend church?

- If you were to look for a church to attend, what kind of things would you look for?

- We're from the Seventh-day Adventist Church. What could we do for you?

What advise can you give a church who really wants to be helpful to people?

- Key issues: listen

- Really listen

- Listen between the lines

- Develop specific responses to the expressed needs

- Develop an evangelistic worship service based on the expressed needs

- $\quad$ Not to replace Sabbath Service

- $\quad$ Probably on Sunday morning

- $\quad$ Whenever it is possible, let religious services be held on Sunday. Make these meetings intensely interesting. Sing genuine revival hymns, and speak with power and assurance of the Saviour's love. Speak on temperance and on true religious experience. You will thus learn much about how to work, and will reach many souls." (9 T 233)

- People in our society expect to go to church on Sunday. We'll give them a place to go where they'll meet Jesus.

- $\quad$ Probably after the first of the year

- New Believer classes for those who accept Christ

- $\quad$ Small Bible study and fellowship groups to develop relationships

- Membership classes when a person decides to become a member of this church 
- We will not assume that accepting Christ is the same as accepting Adventist doctrine

- We will attempt to move people in that direction as a part of their spiritual growth

- Spiritual gifts seminars for those who are ready to consider a ministry

- $\quad$ Evangelistic meetings approximately every 2 years

- $\quad$ Net ' 98 in November, 1998, with Dwight Nelson

- This is something we can do

- I believe God is calling us to do this

- Much study and prayer has gone into this strategy

- I'd like you to prayerfully consider it, too 


\section{APPENDIX B}

PRAYER OFFENSIVE DOOR HANGER

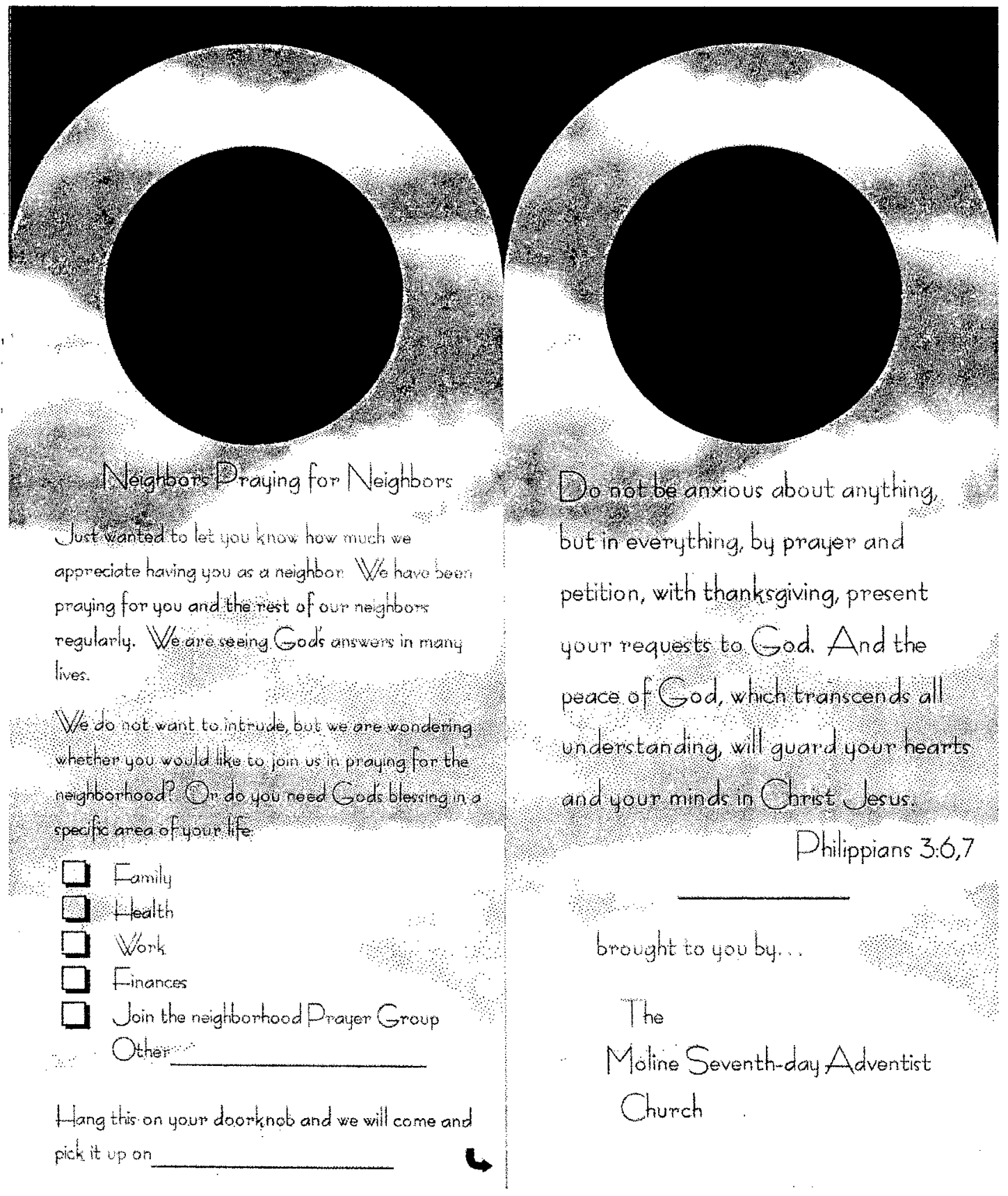

Front

Back 


\section{APPENDIX C \\ COMMUNITY QUESTIONNAIRE, RESULTS, AND INSTRUCTIONS}

\section{Community Questionnaire}

What do you think are the greatest needs in our community?

In your view, how could a church help address these needs?

Are you actively attending any church?

Yes

No

What do you think is the most common reason people don't attend church?

If you were to look for a church to attend, what kind of things would you look for?

What kind of personal services would you expect from a church?

We'd like to pray for the needs of our neighbors. Is there anything you'd like us to pray about for your family? Are there any specific ways we can be of help to you or your family?

We're inviting our neighbors to pray, too. Would you join us in praying for our neighborhood in your personal prayer time?

Pray: Yes No

(By observation mark sex and approximate age:

under 2020 to $35 \quad 35$ to $50 \quad 50$ to $65 \quad$ over 65 .) 


\section{Results}

What do you think are the greatest needs in our community?

-Less violence

-Lower retail taxes. No property taxes. More community involvement in zoning issues.

-Spiritual.

- Community center activities other than sports.

-More family activities.

-Strong families, safe neighborhoods, jobs.

-Instilling respect in our kids.

-More Christianity.

- Crime Control.

-Family Unity.

-Welfare.

-Teens.

-Peace. Keeping kids on the right road.

-Eliminating drug use and violence, especially among young people.

-Positive role models. Safe place for children in the community.

-Youth of today.

-Teenage morale.

-Helping the needy-medical care, children, discouragement, unwed mothers.

- Teach our kids about God.

-Family to be involved in school systems, other community needs.

-People to be considerate of other people's needs.

-Assisting children.

-Dealing with gangs, youth.

-Child care after school.

-Youth guidance, outreach.

In your view, how could a church help address these needs?

-Power structure, keeping church informed.

-By being more actively involved in the community.

-Provide friendship, guidance.

-Seek out youth.

-By going by the Bible.

-Sermons, members discussing the subject.

-More programs including family.

-Personal contact.

-Youth groups.

-More youth programs.

-Parenting groups, after school groups for young people, more family activities. 
-Church can help by providing the children with activities and a place to belong.

-To be involved with youth in all walks of life; get them more involved with positive functions.

-Sponsor programs in community, such as day care for low income working parents-free. Children need home with 2 parents.

-Send kids to church to learn about God.

-Maybe we can do good for others and usually it spreads. Even with people who seem bad:

-Many do programs to be involved in-VBS.

-Finding ways to reach out to families for parenting skills.

- Latch key programs.

-Strong youth programs.

Are you actively attending any church?

Yes No

What do you think is the most common reason people don't attend church?

-Unsure of beliefs, don't want to be "preached at".

-They don't believe or they just don't want to go.

-Dissatisfied with church focus-on self (church) and not the community-especially needy children.

- Lack of time.

-Lazy.

-Finding the right one.

-Laziness.

-It's a lie.

-People don't make time.

-Lack of faith, knowledge of religion.

-Money. Churches asking for too much.

-Think people in church are hypocrites, act one way in church, another out of church

-Discord in life-confusing situation in their life.

-Fear. Guilt. People know the way they live isn't Christlike, but don't understand we're all sinners and still need Christ.

-Motivation.

-In black churches, they feel it's phoney or not really concentrating on what is coming from the heart.

-Loss of faith due to feeling of helplessness or hopelessness.

-Don't want to get up in the morning.

-Lack of involvement.

-Time. 
-Lack of friendliness.

-Work. Not brought up attending church.

- Think life is too busy already.

-Different for everyone.

- They put their time above others.

-Lack of desire.

-Lazy. No need. Too busy.

-Parents force them when they are younger or it doesn't fit in with lifestyle.

If you were to look for a church to attend, what kind of things would you look for?

-One involved in community projects.

-Nice pastor.

-One that's not focused on money! Not focused on foreign missions when so much help is needed here in QC's.

- Family oriented, community oriented church.

-Friendly people, youth programs.

-Friendly and feel welcome.

-Church aren't necessary if people love one another and gather together.

-No Christians.

-Those that worship Jesus.

-Inspirational pastor, youth programs.

-Warm, friendly, family oriented.

-Preaching from Gospel, focus on salvation-not fluff just to make people feel good. -Fellowship.

-A pastor who can speak the Word well-non-condemning, but still honest and firm in the Word.

-Teaching. Bible believing.

-People that are for real and that are interested in the soul of a person, not materialistic values.

-Friendliness of congregation and minister/priest. Groups (Bible study, retreats, etc.)

-I already have a church.

-Sermons. Compatibility with congregation.

-A family oriented church.

- Charismatic.

-Friendliness, age groups.

-Harmony within the congregation.

- One in agreement with my personal convictions.

-A solid church that gets involved.

-Counseling services.

-Church meeting needs.

-Make sure everything is based on the Bible. 
What kind of personal services would you expect from a church?

- To learn about God.

-To counsel family when needed without patronizing or judging. Network community resources when appropriate.

- Recreational programs for adults and children.

-Someone I could talk to.

- Counseling.

- Teaching of God.

- Minister available for questions, assistance.

-Volunteers to give rides to the elderly for doctor appointments and errands.

-Help in finding a nice-small group where they fit in.

-Family activities. Single activities.

-Counseling for dealing with addictive sinful ways.

-Worship

- Communication of talking with people heart to heart and personal.

-Emotional support through times of crisis such as death, divorce, etc.

Confidentiality.

-Place to meet and establish ties.

-Be there when needed.

"I would rather answer, "What can I do?"”

-Babysitting

-Support/counseling when needed.

-Programs geared toward different categories of people in your family.

-Counseling services.

- Food and clothing for ghetto children.

-Every group represented. Kindergarten, married couples, teens, etc. Church isn't just for Sunday.

We'd like to pray for the needs of our neighbors. Is there anything you'd like us to pray about for your family? Are there any specific ways we can be of help to you or your family?

-Pray that drugs stop taking hold of children and adults.

-Pray for safe neighborhoods, reduced crime, good health.

-That I get custody of child.

-For me and mine.

-For the health and safety of my parents and my children.

-School children at school.

-My son and I need family. We have none in this area and would love to have a mother/grandmother figure.

-Children's relationship with God to improve.

-For my family in that they learn everyday of their lives and try not to fall in the snarls of Satan.

-World concerns. 
-Good health.

-Pray that we continue to stand steady in the faith.

-My son and his wife.

-My grandfather with a broken hip.

We're inviting our neighbors to pray, too. Would you join us in praying for our neighborhood in your personal prayer time?

\begin{tabular}{lc}
\hline Yes & No \\
24 & 4 \\
\hline
\end{tabular}

(By observation mark sex and approximate age:

\begin{tabular}{c|c|c}
\hline M & \multicolumn{2}{c}{ F } \\
\hline 8 & 19 & Not Recorded \\
\hline
\end{tabular}

\begin{tabular}{llllll}
\hline Sex & Under 20 & $20-35$ & 35 to 50 & 50 to 65 & over 65 \\
M & 2 & 0 & 6 & 0 & 0 \\
F & 0 & 7 & 8 & 3 & 1 \\
Not & & & & 1 & \\
Recorded & & & & \\
\hline
\end{tabular}




\section{Instructions}

Doing the Questionnaire

Be polite.

Use an introduction similar to this: "Hello, I'm John Doe from the Moline Seventh-day Adventist Church. We're doing a community interest survey to find out how we might be able to better serve our neighbors. Could you spare two minutes to answer eight questions?"

Listen carefully to the replies to the questions. Make accurate notes. Summarize where possible, but feel free to write as much as needed to accurately reflect the answer.

If the person says they don't have time, simply say "Thank you," and go to another house.

If there is no answer when you knock, go on to the next house.

Close the interview by thanking the person for his or her help. Tell the person that our church will be praying for them.

Our goal is to develop a wide enough data base to accurately reflect our community. In order to do this, we need to contact several hundred people. Your help is greatly appreciated. 


\section{SELECTED BIBLIOGRAPHY}

Abernathy, William Beaven. A New Look for Sunday Morning. Nashville, TN: Abingdon, 1975.

Aufderhar, Glenn, and Betty Cooney. How to Hold a Successful Series in Net '98:

Pastor's Evangelistic Training Manual Part 2. Berrien Springs, MI: Net '98, 1998.

Anderson, Leith. A Church for the $21^{\text {st }}$ Century. Minneapolis, MN: Bethany House Publishers, 1992.

. Dying for Change. Minneapolis, MN: Bethany House Publishers, 1990.

Arn, W. Charles. "How to Find Receptive People." In The Pastor's Church Growth Handbook, ed. Win Arn. Pasadena, CA: Church Growth Press, 1979.

Baker, Steve, and others. Good Things Come in Small Groups. Downers Grove, IL: InterVarsity Press, 1985.

Barna, George. Evangelism That Works: How to Reach Changing Generations With the Unchanging Gospel. Ventura, CA: Regal Books, 1995.

. The Frog in the Kettle: What Christians Need to Know About Life in the Year 2000. Ventura, CA: Regal Books, 1990.

. "Has Revival Begun? Our Annual Report on the State of the Christian Church in America," The Barna Report 1, no. 6 (1997): 2, 3.

. Leaders on Leadership: Wisdom, Advice, and Encouragement on the Art of Leading God's People. Ventura, CA: Regal Books, 1997.

. Marketing the Church: What They Never Taught You About Church Growth. Colorado Springs, CO: NavPress, 1988.

. The Power of Vision: How You Can Capture and Apply God's Vision for Your Ministry. Ventura, CA: Regal Books, 1992. 
. "The State of the Church, 1996." The Barna Report 1, no. 2 (1997): 1.

. "The Top 100: Part 1." The Barna Report 1 (May/June 1997): 1.

. User Friendly Churches: What Christians Need to Know About the Churches People Love to Go To. Ventura, CA: Regal Books, 1995.

Bast, Robert L. The Missing Generation. Monrovia, CA: Reformed Church in America, 1991.

Bounds, E. M. The Complete Works of E. M. Bounds on Prayer. Grand Rapids, MI: Baker Book House, 1993.

Brown, Raymond E. John (i-xii). Anchor Bible. Garden City, NY: Doubleday, 1966.

Clinebell, Howard. Basic Types of Pastoral Counseling. Nashville, TN: Abingdon, 1966. . Growth Groups. Nashville, TN: Abingdon, 1977.

Coleman, Robert E. The Master Plan of Evangelism. Old Tappan, NJ: Fleming H. Revell, 1985.

Conway, Jim Men in Mid Life Crisis. Elgin, IL: David C. Cook Publishing Co., 1978.

Covey, Stephen R. The Seven Habits of Highly Effective People. New York: Simon and Schuster, 1990.

Crispell, Diane. "Where Generations Divide: A Guide." American Demographics (May 1993): 9-10.

Dobson, Ed. Starting a Seeker Sensitive Service: How Traditional Churches Can Reach the Unchurched. Grand Rapids, MI: Zondervan Publishing House, 1993.

Dudley, Roger L., and Clarence B. Gruesbeck. Plant a Church, Reap a Harvest. Boise, ID: Pacific Press Publishing Association, 1989.

Ellen G. White Estate. Comprehensive Index of the Writings of Ellen G. White. Mountain View, CA: Pacific Press Publishing Association, 1962.

Engel, James. How Can I Get Then to Listen? Grand Rapids, MI: Zondervan Publishing, 1977. 
Engel, James F., and H. Wilbert Norton. What's Gone Wrong With the Harvest? A Communication Strategy for the Church and World Evangelism. Grand Rapids, MI: Zondervan Publishing, 1975.

Feucht, Oscar E. Everyone a Minister: A Guide to Churchmanship: For Laity and Clergy. St. Louis, MO: Concordia Publishing House, 1986.

Fowler, John W. Evangelism 2000: Proclaiming Christ in the 21 ${ }^{\text {st }}$ Century. Boise, ID: Pacific Press Publishing Association, 1994.

George, Carl F. The Coming Church Revolution: Empowering Leaders for the Future. Grand Rapids, MI.: Fleming H. Revell, 1994.

Gerber, Jerry, and others. Lifetrends: The Future of Baby Boomers and Other Aging Americans. New York: Macmillan Publishing Company, 1989.

Gerber, Vergil. God's Way to Keep a Church Going and Growing. Glendale, Ca: Regal Books, 1973.

Girard, Robert O. Brethren, Hang Loose: Or What's Happening to My Church. Grand Rapids, MI: Zondervan Publishing, 1977.

Hadidian, Allen. Successful Discipling. Chicago, IL: Moody Press, 1979.

Hardin, Grady. The Leadership of Worship. Nashville, TN: Abingdon, 1980.

Haugk, Kenneth C. Antagonists in the Church: How to Identify and Deal With Destructive Conflict. Minneapolis, MN: Augsburg Publishing House, 1988.

Hayford, Jack. Worship his Majesty. Dallas, TX: Word Publishing, 1987.

Holmes, C. Raymond. Sing a New Song! Worship Renewal for Adventists Today. Berrien Springs, MI: Andrews University Press, 1984.

Hunter, Kent R. Moving the Church Into Action. St. Louis, MO: Concordia Publishing House, 1989.

Hybels, Bill. Honest to God? Becoming an Authentic Christian. Grand Rapids, MI: Zondervan Books, 1992.

. Too Busy Not to Pray: Slowing Down to be With God. Grand Rapids, MI: Zondervan Books, 1988. 
Hybels, Lynne, and Bill Hybels. Rediscovering Church. Grand Rapids, MI: Zondervan Publishing House, 1995.

Johnson, David W., and Frank P. Johnson. Joining Together: Group Theory and Group Skills. Boston, MA: Allyn and Bacon, 1991.

Johnson, Douglas W. The Care and Feeding of Volunteers. Nashville, TN: Abingdon, 1988.

Kinlaw, Dennis F. Preaching in the Spirit. Grand Rapids, MI: Francis Asbury Press, 1985.

Kotter, John P. Leading Change, Boston, MA: Harvard Business School Press, 1996.

Leslie, Robert C. Sharing Groups in the Church: An Invitation to Involvement. Nashville, TN: Abingdon, 1971.

Lindgren, Alvin J., and Norman Shawchuck. Let My People Go: Empowering Laity for Ministry. Schaumberg, IL: Organization Resources Press, 1988.

Maslow, Abraham H. Motivation and Personality, New York: Harper and Row, 1970,

Maudlin, Michael G. and Edward Gilbreath. "Selling Out the House of God?" Christianity Todary, July 18, 1994, 21.

Maxwell, C. Mervyn. "Baby Boomers and Moral Leadership" Adventists Affirm, Fall 1991, 9.

Maxwell, John C. Developing the Leader Within You. Nashville, TN: Thomas Nelson Publishers, 1993.

McBride, Neal F. How to Lead Small Groups. Colorado Springs, CO: NavPress, 1992.

McDonough, Reginald M. Keys to Effective Motivation. Nashville, TN: Broadman Press, 1979.

McGavran, Donald A. Understanding Church Growth. Grand Rapids, MI: William B. Eerdmans Publishing Company, 1976.

McGavran, Donald A., and Winfield C. Arn. How to Grow a Church. Glendale, CA: Regal books, 1977.

- Ten Steps for Church Growth. San Francisco, CA: Harper and Row, 1977. 
McIntosh, Gary L. Three Generations: Riding the Waves of Change in Your Church. Grand Rapids, MI: Fleming H. Revell Company, 1995.

McSwain, Larry L., and William C. Treadwell, Jr. Conflict Ministry in the Church. Silver Spring, MD: Ministerial Association, 1997.

Metzger, Will. Tell the Truth: The Whole Gospel to the Whole Person by Whole People. Downers Grove, IL: InterVarsity Press, 1981.

Miller, Calvin. Spirit, Word, and Story: A Philosophy of Preaching. Dallas, TX: Word Publishing, 1989.

Miller, Sherod, Elam W. Nunnally, and Daniel B. Wackman. Alive and Aware: Improving Communication in Relationships. Minneapolis, MN: Interpersonal Communications Programs, 1976.

Minirth, Frank, and others. Steps to a New Beginning: Leading Others to Christ Through the Twelve Step Process. Nashville, TN: Thomas Nelson Publishers, 1993.

Morgan, G. Campbell The Gospel According to John. Westwood, NJ: Fleming H. Revell Company, n.d.

Murren, Doug. The Baby Boomerang: Catching Baby Boomers as They Return to Church. Ventura, CA: Regal Books, 1990.

Neighbor, Ralph W., Jr. Where Do We Go From Here? A Guidebook for Cell Group Churches. Houston, TX: Torch Publication, 1990.

"1990 Census of Population and Housing, Illinois, Rock Island County" [on-line]. Available from http://venus.census.gov/cdrom/lookup; Internet.

Ortiz, Juan Carlos. Call to Discipleship. Plainfield, NJ: Logos International, 1975.

Paulien, Jon. Present Truth in the Real World: the Adventist Struggle to Keep and Share Faith in a Secular Society. Boise, ID: Pacific Press Publishing Association, 1993.

Rittenour, Curtis, ed. Connections. Portland, OR: BBMRC, 1996.

Peterson, Eugene H. Five Smooth Stones for Pastoral Work. Grand Rapids, MI: William B. Eerdmans Publishing Company, 1980.

Rinker, Rosalind. Conversational Prayer. Waco, TX: Word Books, 1970. 
. How to Have Family Prayers. Grand Rapids, MI: Zondervan Publishing, 1977.

Roof, Wade Clark, and others. A Generation of Seekers: The Spiritual Journeys of the Baby Boom Generation. New York: HarperCollins Publishers, 1993.

RPI Publishing. The Twelve Steps: A Spiritual Journey. San Diego, CA: RPI Publishing, Inc. 1994.

Russell, Cheryl. "The Baby Boom Turns 50" American Demographics, December 1995, 22.

Rutz, James H. The Open Church: How to Bring Back the Exciting Life of the First Century Church. Beaumont, TX: The SeedSowers, 1992.

Sahlin, Monte. Sharing Our Faith with Our Friends: Without Losing Either. Hagerstown, MD: Review and Herald Publishing Association, 1990.

Samaan, Philip G. Christ's Way of Reaching People. Hagerstown, MD: Review and Herald Publishing Association, 1990.

Schaller, Lyle E. Assimilating New Members. Nashville, TN: Abingdon, 1990.

Schwartz, Joe. "Boomer Boom" Brandweek, October 8, 1996, 42-47.

Scott, W. Frank. John. Complete Homiletic Commentary on the New Testament. New York: Funk and Wagnalls Company, n.d.

Segler, Franklin M. Christian Worship: Its Theology and Practice. Nashville, TN: Broadman Press, 1967.

Small, Clarence Henry. "Why Aren't Seventh Day Baptists Growing? A Comparative Study of Two Sabbathkeeping Bodies." Paper for the classes "History of Religion" and "History of the Sabbath," Seventh-day Adventist Theological Seminary, Andrews University, 1979.

Smith, J. Walker, and Ann Clurman. Rocking the Ages: The Yankelovich Report on Generational Marketing. New York: HarperCollins Publishers, 1997.

Stevens, R. Paul. Liberating the Laity: Equipping All the Saints for Ministry. Downers Grove, Il: InterVarsity Press, 1985. 
Strobel, Lee. Inside the Mind of Unchurched Harry and Mary. Grand Rapids, MI: Zondervan Publishing House, 1993.

Wagner, C. Peter. Breaking Strongholds: How to Use Spiritual Mapping to Make Your Prayers More Strategic, Effective, and Targeted. Ventura, CA: Regal Books, 1993.

. Churches That Pray: How Prayer Can Help Revitalize Your Congregation and Break Down the Walls Between Your Church and Your Community. Ventura, CA: Regal Books, 1993.

. Prayer Shield: How to Intercede for Pastors, Christian Leaders, and Others on the Spiritual Frontlines. Ventura, CA: Regal Books, 1992.

-Warfare Prayer: How to Seek God's Power and Protection in the Battle to Build His Kingdom. Ventura, CA: Regal Books, 1992.

Warren, Richard. The Purpose Driven Church: Growth Without Compromising Your Message and Your Mission. Grand Rapids, MI: Zondervan Publishing House, 1995.

Watts, Dorothy Eaton. Prayer Country: A Tour to the Wonders of Prayer. Boise, ID: Pacific Press Publishing Association, 1993.

Webber, Robert E. Worship is a Verb. Waco, TX: Word Books, 1985.

White, Ellen G. The Acts of the Apostles. Mountain View, CA: Pacific Press Publishing Association, 1911.

. Colporteur Ministry. Mountain View, CA: Pacific Press Publishing Association, 1953.

. The Desire of Ages Mountain View, CA: Pacific Press Publishing Association, 1940.

. Evangelism. Washington, DC: Review and Herald Publishing Association, 1970.

. Gospel Workers. Washington, DC: Review and Herald Publishing Association, 1936.

. Selected Messages from the Writings of Ellen G. White. Vol. 1. Washington, DC: Review and Herald Publishing Association, 1958. 
- Testimonies for the Church. 9 vols. Boise, ID: Pacific Press Publishing Association, 1948.

. The Ministry of Healing. Mountain View, CA: Pacific Press Publishing Association, 1942.

White, John. Daring to Draw Near: People in Prayer. Downers Grove, IL: InterVarsity Press, 1980.

Wilson, Marlene. How to Mobilize Church Volunteers. Minneapolis, MN: Augsburg Publishing House, 1983.

Yamamori, Tetsunao, and E. Leroy Lawson. Introducing Church Growth: A Textbook in Mission. Cincinnati, OH: New Life Publishing, 1975. 
VITA

CLARENCE H. SMALL (1947-)

Education

Doctor of Ministry

(August, 1999)

Seventh-day Adventist Theological Seminary, Andrews University Berrien Springs, MI Dissertation: An Evangelistic Strategy for Reaching Baby Boomers in Rock Island County, Illinois.

Master of Divinity

Seventh-day Adventist Theological Seminary, Andrews University

Berrien Springs, $M I$

Bachelor of Arts

Southern Missionary College

Collegedale, TN

Major: Communications; Minors: Business and History.

Employment

Pastor/Evangelist

Dakota, Chesapeake, and Illinois Conferences of Seventh-day Adventists

(1980-Present)

Advertising, Sales, and Broadcasting

Various Places

Skills

Primary Spiritual Gifts: Teaching, Evangelism. Trained in Family Life Education. Trained in Small Group Leadership. Led Spiritual Gifts Seminars. Led Vision Development Groups. Led Small Group Leadership Seminars. Conducted Revelation Seminars and Full-scale Evangelistic Series

\section{Personal}

Married to Virginia (nee Fardulis). Two sons: Christopher, currently a minister in the Michigan Conference; and Loren, a junior at Broadview Academy. Interests: books, whitewater rafting, golf, computers. Collect miniature churches. 